\title{
Zn-Pb-Cu sulfide-bearing glacial sandstone erratics near Raahe on the western coast of Finland: Indicators of Paleozoic base metal mineralization at the bottom of the Bothnian Bay
}

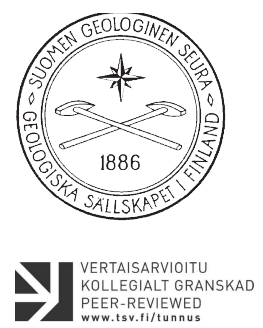

Eero Hanski ${ }^{1}$, Hannu Huhma ${ }^{2}$, Yann Lahaye ${ }^{2}$, Juha Pekka LunkKa ${ }^{1}$, Erik Nilsson ${ }^{3}$, Timo MäKi ${ }^{4}$, Hugh O'Brien'², Kari STRAND ${ }^{1}$

${ }^{1}$ Oulu Mining School, P.O. Box 3000, 90014 University of Oulu, Finland

${ }^{2}$ Geological Survey of Finland, P.O. Box 96, 02151 Espoo, Finland

${ }^{3}$ Atle Arctica, 463 Central Avenue, Mountain View, CA 94043, USA

${ }^{4}$ Näsilinnankatu 7 D 48, 33210 Tampere, Finland

\begin{abstract}
Over the past tens of years, glacial sandstone erratics variably enriched in $\mathrm{Zn}, \mathrm{Pb}$ and $\mathrm{Cu}$ have been collected from the coast south of Raahe, but their source has remained ambiguous. In these non-metamorphosed and non-deformed boulders, detrital grains of quartz and minor feldspar are cemented by calcium carbonate, which is partly or wholly replaced by ore minerals, including sphalerite, galena, pyrite, marcasite, and chalcopyrite. Analyzed mineralized boulders have yielded total base metals contents between 1 and 19 wt.\%. The FeS content in sphalerite is low and variable, ranging commonly between 0.5 and 15 mol.\%, which is in harmony with its coexistence with pyrite.

Galena shows very radiogenic $\mathrm{Pb}$ isotope compositions, with ${ }^{206} \mathrm{~Pb} /{ }^{204} \mathrm{~Pb}$ and ${ }^{207} \mathrm{~Pb} /{ }^{204} \mathrm{~Pb}$ falling in the ranges of $20.55-21.06$ and $15.90-15.94$, respectively. These compositions are similar to those measured for the Laisvall MVT Pb-Zn deposit in the Swedish Caledonides, being consistent with a similar Ordovician age of ore formation. However, $\mathbf{S}$ isotope analyses yielded heterogeneous compositions, with pyrite showing mostly negative $\delta^{34} \mathrm{~S}$ values from -15.6 to $-7.6 \%$, indicating partly a strong bacteriogenic signature, which are distinctly different from the generally heavy sulfur isotope compositions (avg. $\delta^{34} \mathrm{~S}+24 \%$ ) reported from the Laisvall-type deposits, pointing to a different source of sulfur. These results together with some mineralogical differences (relatively abundant chalcopyrite, scarcity of fluorite and barite) suggest that the boulders were not derived from the eastern front of the Caledonian orogen but their provenance occurs much closer, potentially in a so-far-undiscovered occurrence of stratabound base metal mineralization in Cambrian sediments under the Bothnia Bay. The direction of transportation of the sandstone boulders can be estimated using
\end{abstract}


associated carbonate and mafic metavolcanite boulders whose carbon isotope and major and trace element compositions, respectively, indicate their derivations from the Kalix area, northern Sweden.

Keywords: Sandstone, glacial boulder, $\mathrm{Pb}-\mathrm{Zn}$ mineralization, sphalerite, galena, $\mathrm{Pb}-\mathrm{Pb}$ isotopes, Paleozoic, Bothnian Bay

*Corresponding author (e-mail: eero.hanski@oulu.fi)

Editorial handling: Ferenc Molnár (ferenc.molnar@gtk.fi)

\section{Introduction}

Since the early 1950s, mining companies and the Geological Survey of Finland (GTK) have received numerous samples of non-metamorphosed $\mathrm{Zn}-\mathrm{Pb}$ sulfide-bearing sandstone erratics which amateur prospectors have collected on the eastern shore of the Bothnian Bay, south of Raahe (Figs. 1-3). These samples have promoted several campaigns to characterize the mineralogy and chemistry of the ore-bearing sandstone boulders. These previous studies have mostly been presented in unpublished research reports (e.g., Saastamoinen, 1981; Niemelä, 1983). Based on the non-metamorphosed nature of the mineralized sandstone erratics, it is obvious that they have been transported by glacial drift from a place somewhere in the northwest, as the bedrock in the Raahe area consists of Paleoproterozoic plutonic and supracrustal rocks of the Svecofennian province. Yet, the exact source area has remained ambiguous. Because of their non-metamorphosed nature and metal content dominated by $\mathrm{Zn}$ and $\mathrm{Pb}$, the mineralized sandstone boulders may have a potential connection to the processes that formed the Laisvall-type $\mathrm{Pb}-\mathrm{Zn}$ deposits hosted by late Ediacaran to Lower Cambrian sandstones at the eastern edge of the Caledonides in Sweden and Norway. In general, the known Paleozoic sandstonehosted $\mathrm{Pb}-\mathrm{Zn}$ deposits occur along the Caledonides front, with few occurrences being found around basement windows within the Caledonides (e.g., Rickard et al., 1979; Saintilan et al., 2016). To the east of the Caledonian front, the exposed bedrock is composed mainly of older Svecofennian granitoids and supracrustal rocks and Laisvall-type sandstonehosted mineralization is absent. The Raahe boulders occur around $375 \mathrm{~km}$ east-southeast of Laisvall, which makes their derivation from such a distant source unlikely.

In this paper, we summarize the results of earlier studies and present new petrographical, mineralogical, and $\mathrm{Pb}-\mathrm{Pb}$ and $\mathrm{S}$ isotope data from sulfide-bearing Raahe sandstone boulders. These data are used to compare them with the Laisvalltype ore deposits and put constraints on their age and source region.

\section{Laisvall-type sandstone- hosted $\mathrm{Pb}-\mathrm{Zn}$ deposits}

Several hundreds of individual occurrences of $\mathrm{Pb}-\mathrm{Zn}$ mineralization have been recognized along the entire eastern erosional front of the Scandinavian Caledonides, extending $2000 \mathrm{~km}$ from the Arctic Ocean in the north to SW Norway in the south (Fig. 1). They mostly occur in Sweden (Grip, 1960; Rickard et al., 1979; Casanova, 2010; Saintilan et al., 2015a, 2016), but some have also been discovered in Norway (Bjørlykke \& Sangster, 1981). Mineralization is associated with autochthonous late Ediacaran to CambroOrdovician clastic sedimentary rocks, which were deposited on older Paleoproterozoic crystalline 


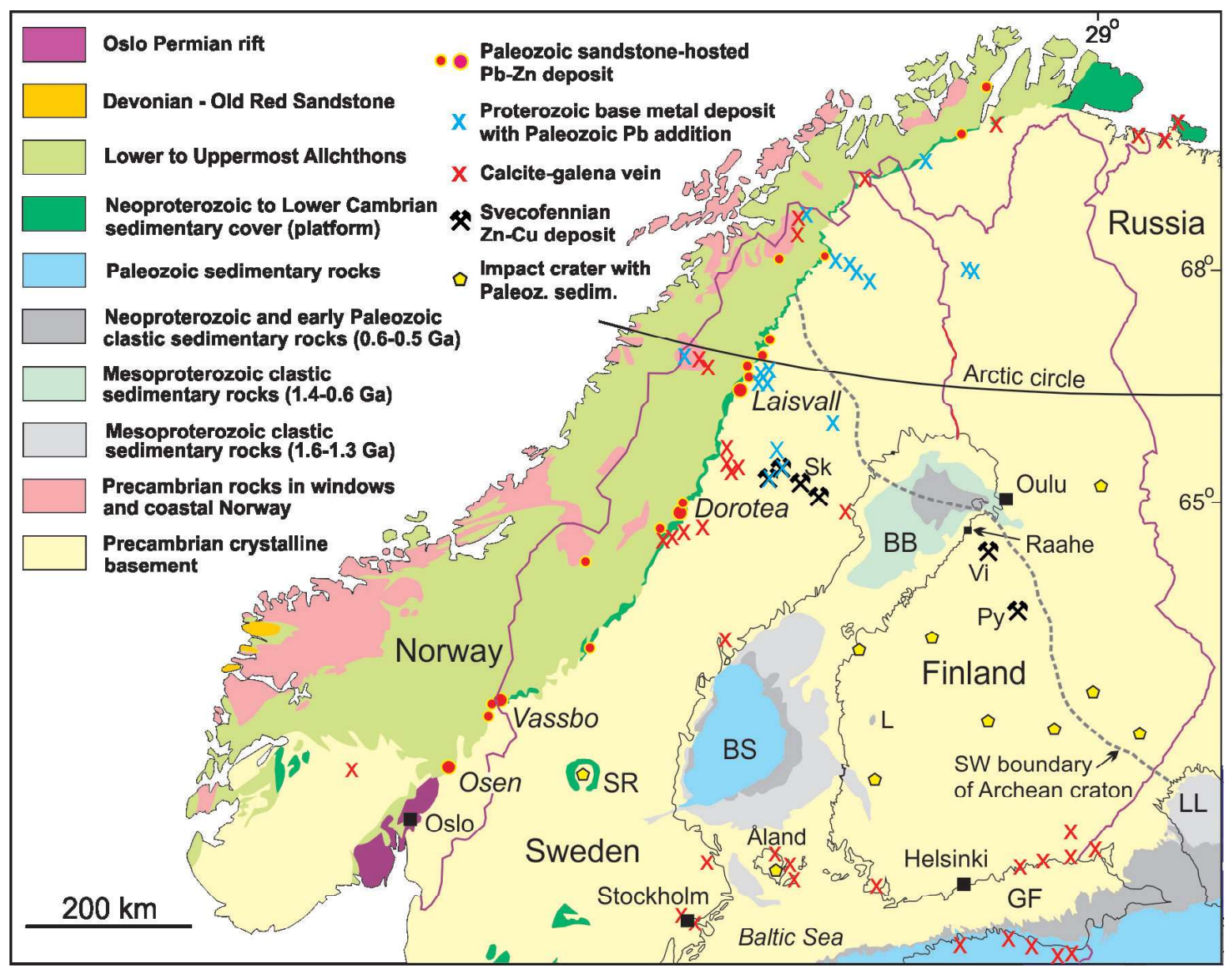

Figure 1. Occurrences of Paleozoic sandstone-hosted MVT Pb-Zn deposits (red filled circles) at the eastern front of the Caledonides and the location of the Raahe boulders on the eastern shore of the Bothnian Bay (map modified after Kohonen \& Rämö, 2005, and Gee et al., 2008). Also shown are locations of Svecofennian VMS deposits in the RaaheLadoga belt in Finland and the Skellefte belt in Sweden, calcite-fluorite-galena veins, impact craters filled with Lower Paleozoic sediments, and Paleoproterozoic base metal deposits containing Phanerozoic Pb addition (Bjørlykke et al., 1990; Romer, 1990, 1993, 1994; Romer \& Wright, 1993; Mänttäri, 1995). Gray dashed line marks the SW border of the Archean crust drawn after Lahtinen et al. (2016) and Hellström et al. (2018). Abbreviations: BB = Bothnian Bay, $B S=$ Bothnian Sea, GF = Gulf of Finland, $L=$ Lauhanvuori, $L L=$ Lake Ladoga, Py $=$ Pyhäsalmi, Sk = Skellefte district, $\mathrm{SR}=$ Siljan Ring structure, $\mathrm{Vi}=$ Vihanti.

basement and later overthrust by Caledonian nappes. In some places, $\mathrm{Pb}-\mathrm{Zn}$ sulfides are also found in the lowermost nappe sheet (Ayrault, 2008) or in calcite veins in the underlying basement (Johansson, 1983). The most well-known and economically important of the $\mathrm{Pb}-\mathrm{Zn}$ deposits is that of the type locality, the world-class Laisvall deposit (Rickard et al., 1979; Casanova, 2010; Saintilan et al., 2015b, 2016), which is located in northern Sweden around $10 \mathrm{~km}$ south of the Arctic circle (Fig. 1). The Laisvall mine was the principal lead producer in Europe during its exploitation between 1943 and 2001, producing 64.3 Mt of ore averaging 4.0 wt.\% Pb, 0.6 wt.\% $\mathrm{Zn}$ and $9 \mathrm{~g} / \mathrm{t} \mathrm{Ag}$ in grade (Willdén, 2004). Two other deposits, Vassbo and Guttusjö (Christofferson et al., 1979), which are located approximately $500 \mathrm{~km}$ to the SSW from Laisvall, have also been in production. Other significant so-far-unexploited deposits include Lövstrand in the Dorotea area (Ayrault, 2008). 
At Laisvall, the ore-bearing sandstone is part of an approximately 90-m-thick transgressive siliciclastic sedimentary sequence capped with an organic-rich black shale called the Alum Shale Formation (Rickard et al. 1979; Saintilan et al. 2016). There exist two nearly horizontal mineralized feldspathic sandstone units, the Lower and Upper Sandstones, with thicknesses of 25 and $11 \mathrm{~m}$, respectively, representing the most permeable paleoaquifer parts of the sedimentary pile. The dimensions (thickness/width/length) of the stratabound metal enrichment in the lower layer are 2-24 $\mathrm{m} / 200-600 \mathrm{~m} / 5000 \mathrm{~m}$ and in the upper layer 2-8 m/300-1000 m/2000 m. Pore space between detrital quartz and minor feldspar grains is filled by sulfides, calcite, fluorite, and barite. Sulfides are dominated by galena, which is accompanied with sphalerite, with the pyrite content in ore being low (avg. $0.2 \%$ ) and that of chalcopyrite very low. This ore mineral assemblage results in high $\mathrm{Pb} / \mathrm{Zn}$ with an average value of $8: 1$, though the upper part of the deposit is richer in $\mathrm{Zn}$, which may reach values up to 4 wt.\% (Saintilan et al., 2016).

The Laisvall-type $\mathrm{Pb}-\mathrm{Zn}$ deposits are generally regarded as a subtype of the Mississippi Valleytype (MVT) Pb-Zn deposits (e.g., Rickard et al., 1979; Saintilan et al., 2016), which they resemble in their tectonic setting and ore mineral assemblages. They are different from typical MVT ores in being hosted by sandstones rather than carbonate rocks and characterized by exceptionally high galena/sphalerite ratios. Consequently, Robb (2005) regards the Laisvall-type deposits as an intermediate category between stratiform sediment-hosted copper (SSC) ores and MVT leadzinc ores. Controversial opinions still exist on the classification of the deposits as revealed by the recent disbute between Sangster (2018) and Fontboté and Saintilan (2018).

Rickard et al. (1979) concluded that the mineralization event at Laisvall postdated sediment consolidation but was earlier than the sandstone lithification caused by the thrusting of the Caledonian nappes in the area. Sherlock et al. (2005) discovered two populations of Ar-Ar ages for authigenic potassium feldspar overgrowths, with the older one being Precambrian-Cambrian $(528 \pm 10$ to $567 \pm 8 \mathrm{Ma})$ and the younger one Upper Ordovician to Early Devonian ( $453 \pm 8$ to $403 \pm 6 \mathrm{Ma})$. Using the Rb-Sr system, Saintilan et al. (2015a) were able to constrain the mineralization age at $467 \pm 5 \mathrm{Ma}$, i.e., being Middle Ordovician and approximately $80-100 \mathrm{Ma}$ younger than the age of the hosting Ediacaran-Cambrian sedimentary rocks. This would mean that the mineralization is clearly epigenetic in nature and was generated by hydrothermal fluids percolating through porous sandstone layers. It has been proposed that hydrothermal fluid circulation took place in a foreland basin setting during the early stages of the Caledonian orogeny (e.g., Duane $\&$ de Wit, 1988 ), with sulfide precipitation at temperatures of 120 to $180{ }^{\circ} \mathrm{C}$ being caused by the interaction of two fluid systems, involving mixing of reduced sulfide-bearing fluids and oxidized, saline, slightly acidic metal-bearing basinal brines from deeper parts of the basin (Rickard et al., 1979; Saintilan et al., 2015b, 2016). According to Saintilan et al. (2016), hydrocarbons derived from overlying carbon-rich sediments played an important role in producing $\mathrm{H}_{2} \mathrm{~S}$ by thermochemical reduction of earlier-formed sulfates. It needs to be added that the view of Middle Ordovician timing of the $\mathrm{Pb}-\mathrm{Zn}$ ore formation and its connection of the Caledonian orogeny is not shared by all investigators. Based on $\mathrm{Pb}$ isotope evidence, Bjørlykke and Thorpe (1982) and Bjørlykke et al. (2019) suggest that in the Osen deposit, the precipitation of $\mathrm{Pb}-\mathrm{Zn}$ sulfides took place during the diagenesis of the host sandstone at ca. $540 \mathrm{Ma}$, with metals being derived by chemical weathering of the underlying ca. $1675 \mathrm{Ma}$ granitoid basement 


\section{Geological background}

\subsection{Precambrian bedrock}

The Raahe area is part of the 1:100000 scale map sheet of Raahe-Paavola constructed by Nykänen (1959). The area occurs in the Bedrock Map of Central Fennoscandia (Mid-Norden) (Lundqvist \& Autio, 2000), which forms the base for the geological map shown in Fig. 2. The bedrock geology of the area is complex for several reasons. It is located close to the hidden SW boundary of the Archean Karelia craton indicated by a dashed blue line in Fig. 1. The exposed bedrock in the Raahe area belongs to the Svecofennian domain as defined by Lahtinen et al. (2005) or to the Svecofennia province using the most recent terminology of Luukas et al. (2017). The Svecofennian rocks constitute several arc complexes of which the Savo belt (also known as the Primitive arc complex of central Finland; Vaasjoki et al., 2005) and the central Svecofennia meet in the Raahe area (Kähkönen, 2005). According to Kähkönen (2005), the supracrustal rocks of the Savo belt comprise -1.93-1.92 Ga felsic, intermediate, and mafic volcanic rocks and mica gneisses and mica schists with intercalated carbonate rocks. Kähkönen (2005) assignes the northernmost part of the central Svecofennia, approaching Raahe, to the Pohjanmaa belt and more specifically, to the Ylivieska field of that belt, with the supracrustal rocks being composed of $-1.90-1.88 \mathrm{Ga}$ mafic, intermediate and felsic volcanic rocks with sedimentary intercalations and mica schists with intercalated arenites and conglomerates. Granitoids in the coastal area are typical syn- to postorogenic granodiorites, tonalites, quartz diorites and granites ranging in age from $\sim 1.89$ to $1.87 \mathrm{Ga}$.

The volcanic rocks of the Savo belt are characterized by occurrences of VMS-type mineralization (Mäki et al., 2015), with the Vihanti Zn-Pb-Ag deposit being located around $40 \mathrm{~km}$ south-east of the coast (Figs. 1,2). The supracrustal rocks of the Raahe area were metamorphosed under amphibolite facies conditions, which contrasts with the non-metamorphosed nature of the sandstone boulders.

\subsection{Muhos and Hailuoto Formations}

The youngest known rocks in the Bothnian Bay region are represented by the non-metamorphosed Meso- to Neoproterozoic sedimentary formations that are called the Muhos and Hailuoto Formations, occurring south of Oulu and on the Hailuoto Island, respectively, and in their extensions under the modern-day sea (Kohonen \& Rämö, 2005) (Figs. 1, 2). The Muhos Formation extends roughly $50 \mathrm{~km}$ from the coast inland as a NW-trending $20-\mathrm{km}$ wide rift zone, and in the sea area, it is assumed to cover the main part of the Bothnia Bay, stretching south to the Kokkola area (Fig. 1; Ignatius et al., 1980) and being only approximately $20 \mathrm{~km}$ from the coast where the Raahe sandstone boulders have been found (Fig. 2). The Hailuoto Formation lies on the Muhos Formation and extends around $100 \mathrm{~km}$ west of the Hailuoto Island.

Both the Muhos and Hailuoto Formations are poorly exposed and their lithology and stratigraphy is based on drillhole information. The Muhos Formation reaches a thickness of at least $900 \mathrm{~m}$ (Kousa \& Lundqvist, 2000) and rests unconformably on the Precambrian bedrock, having conglomerates and arkosic sandstone in its lowermost part. According to Simonen and Kouvo (1955), red and brown siltstones with thin interbeds of arkosic sandstone represent $80-90 \%$ of the whole thickness of the Muhos Formation. The age of the Muhos Formation is poorly constrained and assumed to be around 1.3 Ga based on K-Ar dating (Simonen, 1960) and microfossil data (Tynni \& Uutela, 1984). The formation has been correlated with the Mesoproterozoic sandstones in the Satakunta area and their extensions under the Bothnian Sea (Kohonen \& Rämö, 2005).

Drillholes and seismic studies indicate that the thickness of the Hailuoto Formation varies between 100 and $500 \mathrm{~m}$ (Veltheim, 1969). Lithologically, 


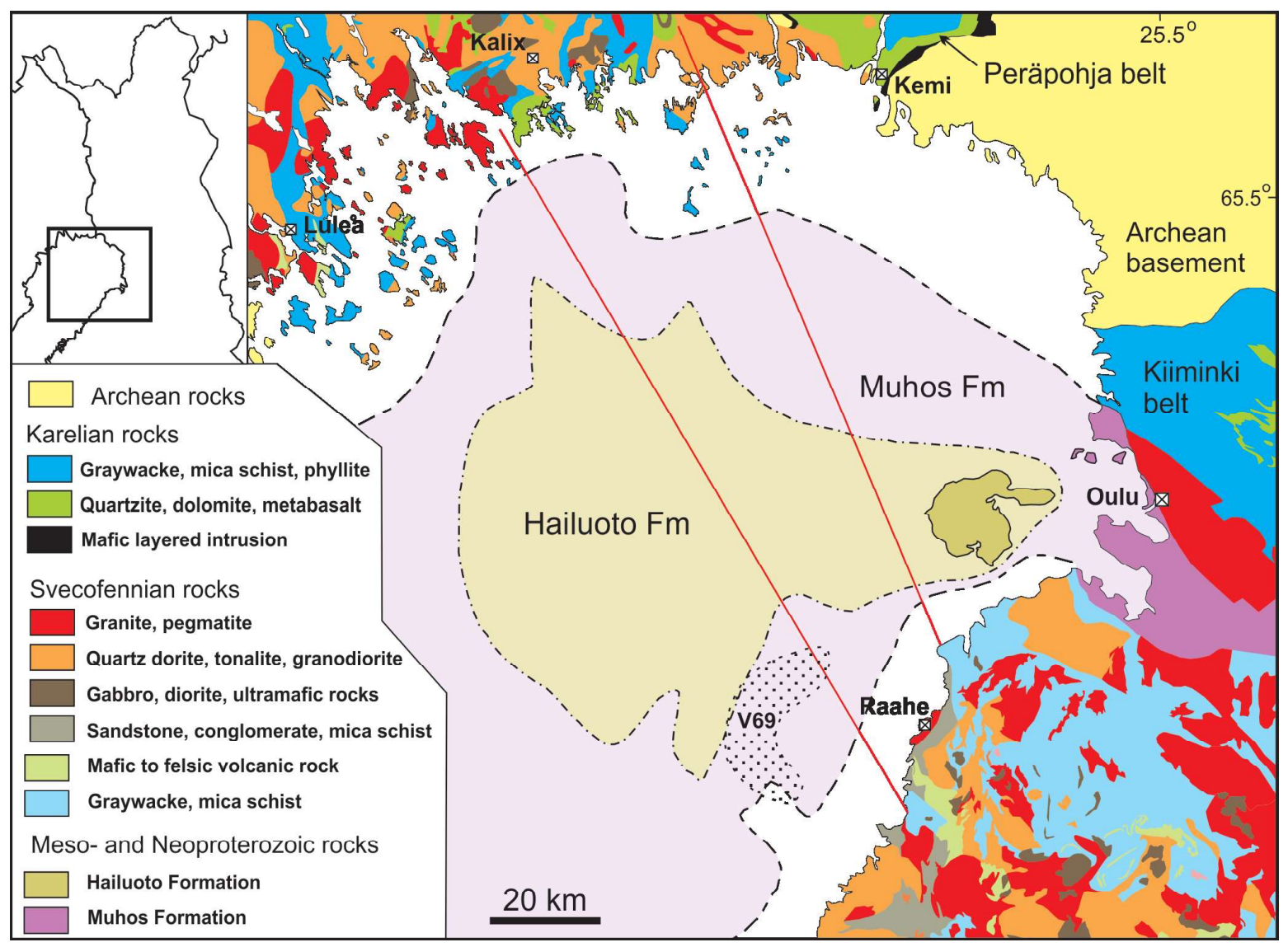

Figure 2. Geological map of the Bothnian Bay region (modified after the Bedrock Map of Central Fennoscandia; Lundqvist \& Autio, 2000). Dashed lines denote the assumed offshore limits of the Muhos and Hailuoto Formations beneath the Bothnian Bay. Red lines represent potential transport directions of quartzite, dolomite and mafic volcanite boulders found in the Raahe area, which are thought to be derived from the Karelian formations in the Kalix area, Sweden. The dotted area west of Raahe marked with V69 represents the potential source area of the mineralized sandstone boulders as proposed by Veltheim (1969).

the Hailuoto rocks are coarser grained and more light-colored compared to those of the Muhos Formation, consisting mostly of pale pink or light greenish subarkose interbedded with siltstone and mudstone (Veltheim, 1969). Veltheim (1969) does not mention the presence of sulfides in the Hailuoto drillcores, except tiny sparse pyrite grains in shale layers. The interpreted contact between the Hailuoto Formation and the underlying Muhos Formation has been penetrated by a drillhole (R2 of Veltheim, 1969). If this is true, this contact would represent a hiatus of hundreds of millions of years as the available microfossil data indicate a Neoproterozoic age of ca. 650-570 Ma for the Hailuoto Formation (Tynni \& Donner, 1980). This age range seems to be still an overestimate if the correlation of the Hailuoto Formation with the Lower Cambrian sandstones and siltstones overlying the Jotnian (Satakunta) sandstones beneath the Bothnian Sea is valid (Fig. 1; Kohonen \& Rämö, 2005; Nielsen \& Schovsbo, 2011, 2015). These Cambrian sediments are covered by still younger Ordovician limestones in the Bothnian Sea area (Winterhalter, 2000). 


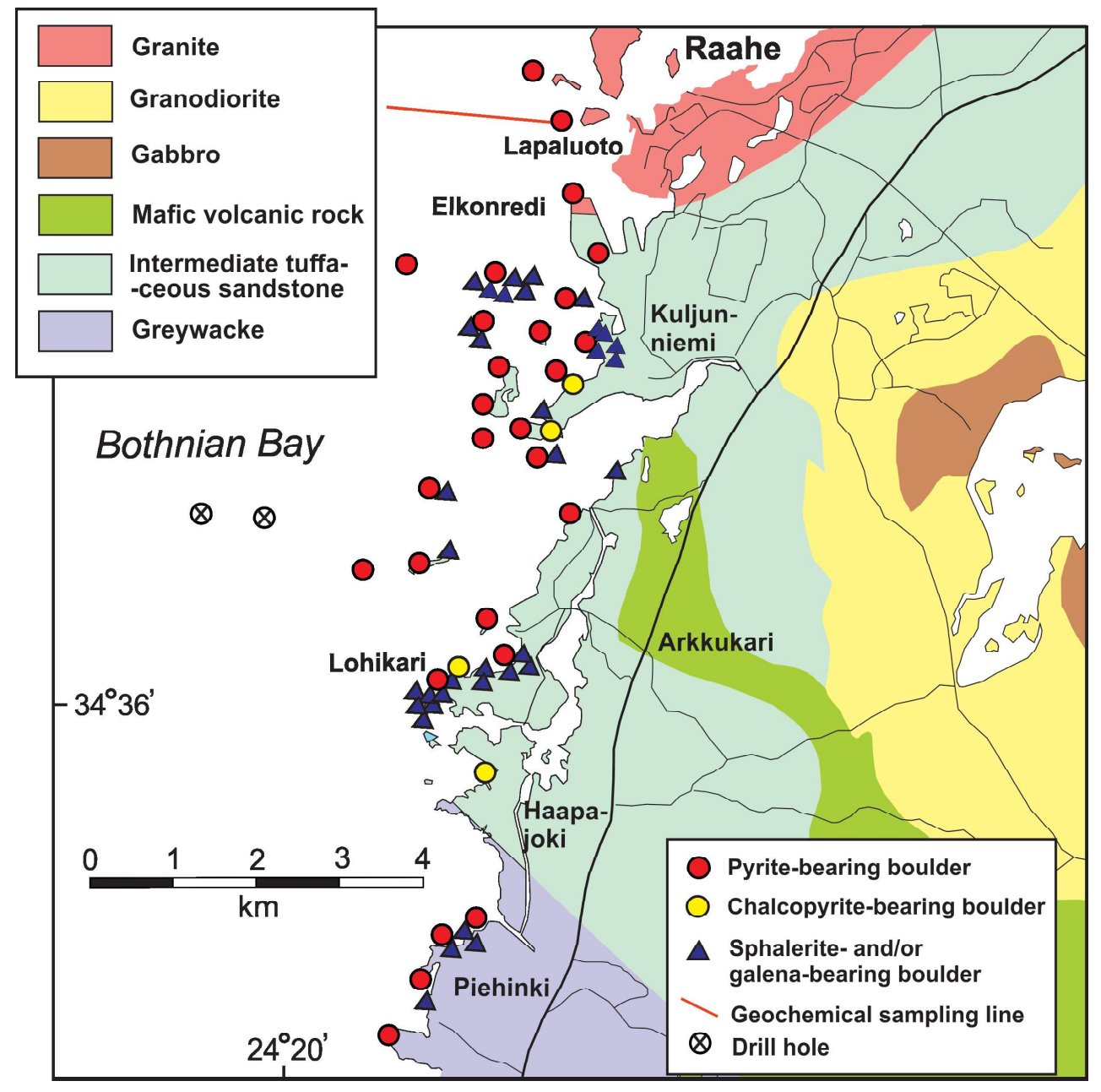

Figure 3. Geological map of the Raahe area modified after DigiKp (2018) and locations of mineralized boulder findings after Makkonen (1971) and Niemelä (1983). Also shown are the locations of a geochemical sampling line of the Quaternary sediment cover near Lapaluoto (red line; after Niemelä, 1983) and two drillholes under the Bothnian Bay made by Nykänen (1959).

\subsection{Quaternary deposits}

The Quaternary sediments covering the Precambrian bedrock in the Raahe area consist mainly of Middle and Late Pleistocene tills and glaciofluvial sediments overlain by Holocene Baltic Basin sediments, i.e. silt/clay and organic-rich fine sediments as well as Holocene fluvial, littoral and aeolian sands and peat (Niemelä et al., 1993). Glacial sediments were deposited by the Scandinavian Ice Sheet, which overran the area several times during the Pleistocene glaciations (Lunkka et al., 2004; Johansson et al., 2011). Previous workers have reported a total of three different ice movement directions in the Raahe and adjacent areas deduced from bedrock striae, till clast fabric and landform lineation data (Hellaakoski, 1940; Hyyppä, 1948; Okko, 1949; Nenonen et al., 1991; Iisalo, 1992, 2003; Nenonen, 1995; Lunkka et al., 2016). Till clast fabric observations made at Mertuanoja, $60 \mathrm{~km}$ south of Raahe, indicate that the Late Saalian till unit beneath the Eemian interglacial sediments was deposited by ice from the NW $\left(310^{\circ}-320^{\circ}\right)$. Around Raahe in the Vihanti and Haapavesi areas comparable, so-called "lower till unit" also indicate an ice movement direction from the NW $\left(320^{\circ}-330^{\circ}\right)$ (Nenonen et al., 1991; Nenonen, 1995). Two ice flow phases, the older 
from the west/west northwest $\left(270^{\circ}-300^{\circ}\right)$ and the younger from the northwest/north $\left(330^{\circ}-360^{\circ}\right)$ post-date the Late Saalian ice flow phase. Based on previous studies, it can be therefore concluded that the oldest glacial sediments (tills and glaciofluvial sands and gravels) discovered in the the western coastal area in the Raahe region are thought to have been deposited during the Saalian Glaciation advancing prior to $130 \mathrm{ka}$ from $310^{\circ}-330^{\circ}$ while the two younger ice flows across the area took place during the Middle and Late Weichselian times from $270^{\circ}-300^{\circ}$ and $330^{\circ}-360^{\circ}$, respectively (Nenonen, 1995; Lunkka et al., 2016). There are only some provenance studies carried out from glacial sediments in the Raahe and adjacent areas, which basically indicate that sandstones containing $\mathrm{Pb}-\mathrm{Zn}$ sulfides were derived from WNW-NW $\left(290^{\circ}-320^{\circ}\right)$ (Hyyppä, 1948; Huhta, 1985).

The last deglaciation in the Raahe area took place at around $10 \mathrm{ka}$ ago during the Ancylus Lake phase of the Baltic Basin (cf. Cuzzone et al., 2016). The margin of the Scandinavian ice sheet terminated into deep water (water depth more than $200 \mathrm{~m}$ ) in the northern coastal areas of the Bothnian Bay including the Raahe area (cf. Donner, 1995). The water depth on shore and off-shore to the east and west in the Bothnian Bay promoted ice front calving and long-distance ice berg transportation of mineral material in ice bergs. Due to glacioisostatic uplift, the water level regressed in the Bothnian Bay during the Holocene and the Ancylus Lake and subsequent Litorina Sea sediments became partially eroded and overlain by littoral, fluvial sediments and peat bogs.

\section{Previous studies}

In connection to the mapping of the Raahe-Paavola map sheet, the Geological Survey of Finland made two drillholes to the sea bottom west of the Siniluoto harbor in 1958 to test the existence of young sedimentary rocks in the area (Fig. 3). Only Precambrian phyllites were discovered. Nykänen (1959) concluded that at least for a distance of $6 \mathrm{~km}$ from the shore, phyllites similar to those seen in the coastal area exist in the seafloor bedrock. Precambrian mica schists were also encountered in the Nahkiainen beacon area around $20 \mathrm{~km} \mathrm{WSW}$ of Raahe where, in 1964, Otanmäki Oy targetted four drillholes at a magnetic anomaly several $\mathrm{km}$ in length. The anomaly turned out to be caused by a 50-m-thick, magnetite-rich iron formation interlayer within mica schist (Hytönen, 1968).

In his account on the pre-Quaternary geology of the Bothnian Bay area, Veltheim (1969) presents the first published description of mineralized sandstone cobbles and boulders picked from the shore of the Lohikari cape, around $10 \mathrm{~km} \mathrm{SSW}$ of Raahe. He mentions pyrite, marcasite, galena, sphalerite, and chalcopyrite as the main ore minerals and safflorite ( $\left.\mathrm{CoAs}_{2}\right)$ as a curiosity. He also analyzed two richest samples, obtaining $18.5 \mathrm{wt} . \%$ $\mathrm{Zn}$ and $3.4 \mathrm{wt} . \% \mathrm{~Pb}$ for one and $8.8 \mathrm{wt} . \% \mathrm{Zn}$ and 7.15 wt. $\% \mathrm{~Pb}$ for the other. By means of a marine grab, Veltheim (1969) carried out a wide sampling of sea bottom glacial drift sediments over the Bothnian Bay. He does not mention a discovery of a single fragment of ore-bearing sandstone on the sea floor. Nevertheless, he delineated a sandstone area $10 \times 30 \mathrm{~km}$ in size, occurring north of the Nahkiainen beacon, around $20 \mathrm{~km}$ west of Raahe, and proposed that the sulfide-bearing sandstone erratics originate from this area. It should also be mentioned that Veltheim (1969) did not equate the sandstone boulders with the sedimentary rocks that he had studied in the drillcores from the western part of the Hailuoto Island.

Makkonen (1971) reported results of the boulder search which was carried out by the Rautaruukki Company in 1970. Most analyzed samples were rich in iron sulfides, though some had moderate amounts of $\mathrm{Pb}$ and $\mathrm{Zn}$ and one had a $\mathrm{Cu}$ content of $>10$ wt. $\%$. He mentions that samples received from laymen prospectors include one with 7.85 wt. $\% \mathrm{Cu}$, six with $2.7-6.3$ wt. $\% \mathrm{~Pb}$, and five with 2.0-23.7 wt.\% Zn.

Saastamoinen (1981) reported on boulders sent by laymen prospectors to the Outokumpu Oy Company. His report includes whole-rock compositions, in which $\mathrm{Cu}, \mathrm{Zn}$ and $\mathrm{Pb}$ reach values 
of approximately 2.5, 10 and 4 wt.\%, respectively, and also sphalerite compositions determined by electron microprobe, showing that they are relatively low in $\mathrm{Fe}$ (avg. 3.0 wt.\%). He notes that taken into account the uneven distribution of the sulfides and the non-representativeness of the random samples, the high concentrations found in some samples do not have much weight. He assumes that the source of the boulders is the 10x30-km-sized sandstone area that Veltheim (1969) had delineated north of the Nahkiainen beacon based on dredging of sea-floor sediments, though no mineralized samples were discovered in these operations.

So far, the most comprehensive account on the Raahe erratics is the report by Niemelä (1983), which is based on the boulder search conducted by the GTK at the coast and islands in 1981. A large number of new mineralized cobbles and boulders were found in the area shown in Fig. 3. Niemelä (1983) could constrain the distribution of the sulfide-bearing sandstone boulders; no boulders were discovered on the coast north of Raahe town, but pyrite concretions or pyrite-, galena- and sphalerite-bearing sandstone erratics were found on most islands on the SW side of the town and along the coast to the SSW over a distance of about $10 \mathrm{~km}$.

Niemelä (1983) made a comparison between the Raahe sandstones and the sedimentary rocks occurring in the Muhos Formation, including those of Hailuoto Island, which had been described earlier by Simonen and Kouvo (1955) and Veltheim (1969), among others. The Muhos Formation is mainly made up of red and brown (oxidized) siltstones whereas the proportion of sandstones and conglomerates is less than $10 \%$ and the sandstones are less mature compared to Raahe boulders. Other differences include the absence of sulfides with the exception of minor rare pyrite in the Muhos Formation.

Niemelä (1983) also reported results of the sampling of the sea bottom by percussion drilling conducted along three lines in 1982. The southernmost sampling line is presented in Fig. 3. Totally around 30 sampling points yielded chips from solid rock under the Quaternary sediment cover, which turned out to be mostly metavolcanic rocks, granites, and gneisses. In addition, the metal contents of the analyzed samples of the sedimentary cover were not particularly elevated. Thus, no tangible evidence was obtained by these studies for the existence of Paleozoic source rocks for the Raahe erratics in the near-shore area. Nevertheless, the density of the sphalerite- and galena-bearing sandstone boulders suggested to Niemelä (1983) that they rather originated from a sandstone formation occurring closer to the shore than the continuous sandstone-siltstone formation in the Bothnian Bay area in the map published by Ignatius et al. (1980) (Fig. 2).

The first $\mathrm{Pb}-\mathrm{Pb}$ isotope analyses on galena in mineralized boulders from the Raahe area were conducted by Matti Vaasjoki at the GTK in the 1990's. Numerical results of these analyses were not published; the study was only mentioned in a report by Nikander (2000) where he states that, according to Vaasjoki, the $\mathrm{Pb}$ isotope composition is similar to that in a galena vein occurring in Cambrian sandstone in $A$ land (Bergman \& Lindberg, 1979).

\section{Sampling and analytical methods}

Sandstone samples from the Raahe area were partly received from Pyhäsalmi Mine Oy, being originally samples that were sent by layman prospectors to the company. We also utilized samples discovered by GTK exploration geologists in the 1970s and early 1980s. The rest of the samples were collected by the first author in 2015 and 2016.

Compositions of ore minerals were measured by a Jeol JXA-8200 electron probe microanalyzer housed in the Center of Microscopy and Nanotechnology (CMNT), the Oulu University. The following operating conditions were used: voltage of $15 \mathrm{kV}$, current of $5 \mathrm{nA}$, and spot size $5 \mu \mathrm{m}$.

Metal and sulfur contents in whole-rock samples were determined by ALS Scandinavia AB in Öjebyn, Sweden, using four-acid digestion and 
analysis by inductively coupled plasma atomic emission spectrometry (ICP-AES). In addition, we have earlier XRF data on sandstone boulders provided by Pyhäsalmi Mine Oy. Bulk-rock compositions of mafic metavolcanite boulders were determined at Bureau Veritas Commodities Canada Ltd. in Vancouver, Canada, using fused sample discs and X-ray fluorescence spectroscopy (XRF) for major and minor elements and inductively coupled plasma mass spectrometry (ICP-MS) for trace elements.

Recent lead isotope analyses of galena were performed at the Geological Survey of Finland in Espoo using a $\mathrm{Nu}$ Plasma HR multicollector ICPMS combined with a Photon Machine Analyte G2 laser microprobe. Samples were ablated in $\mathrm{He}$ gas (gas flows $=0.4$ and $0.1 \mathrm{l} / \mathrm{min}$ ) within a HelEx ablation cell (Müller et al., 2009). The $\mathrm{He}$ aerosol was mixed with $\mathrm{Ar}$ (gas flow $=1.1 \mathrm{l} / \mathrm{min}$ ) prior to entry into the plasma. The gas mixture was optimized daily for maximum sensitivity. All analyses were carried out in static ablation mode. Ablation conditions were: beam diameter: $3-5 \mu \mathrm{m}$, raster speed: $1 \mu \mathrm{m} /$ second, pulse frequency: $5 \mathrm{~Hz}$, beam energy density: $0.83 \mathrm{~J} / \mathrm{cm}^{2}$. An analysis session consists of periodic baseline measurements, while each separate analysis consists of 1 block of 20 ratios. The MC-ICP-MS is equipped with 9 Faraday detectors and amplifiers with $10^{11} \Omega$ resistors. During the ablation the data were collected in static mode $\left({ }^{208} \mathrm{~Pb},{ }^{207} \mathrm{~Pb},{ }^{206} \mathrm{~Pb},{ }^{204} \mathrm{~Pb},{ }^{205} \mathrm{Tl},{ }^{203} \mathrm{Tl}\right)$. The raw data were filtered at $2 s$ and corrected for mass discrimination using an exponential law. The mass discrimination factor for $\mathrm{Pb}$ was determined using a $10 \mathrm{ppb} \mathrm{Tl}$ solution nebulized at the same time as the sample, using a desolvating nebulizer. Slight inhomogeneity of our older in-house standard GPG1 is apparent in the $2 \sigma$ results calculated for the time when these measurements were made. Instrument ${ }^{206} \mathrm{~Pb} /{ }^{204} \mathrm{~Pb},{ }^{207} \mathrm{~Pb} /{ }^{204} \mathrm{~Pb}$ and ${ }^{208} \mathrm{~Pb} /{ }^{204} \mathrm{~Pb}$ ratio precision is $<0.08 \%(2 \sigma)$ on a homogenous galena standard purchased more recently. In this work, we also report results of lead isotope analyses of galena obtained by Matti Vaasjoki with thermal ionization mass spectrometry at the Geological
Survey of Finland, Espoo, in the 1990's. For details of the analytical techniques, the reader is referred to Vaasjoki and Vivallo (1990).

Sulfur isotope analyses of pyrite and marcasite were performed using the same instrumentation as for lead isotopes (see above). Samples were ablated in He gas (gas flows $=0.4$ and $0.11 / \mathrm{min}$ ) within a HelEx ablation cell (Müller et al., 2009). Sulfur isotope compositions were measured at medium resolution. During the ablation, the data $\left({ }^{32} \mathrm{~S},{ }^{34} \mathrm{~S}\right)$ were collected in static mode. Single spot pyrite samples were ablated at a spatial resolution of 40 micrometers, using a fluence of $3.5 \mathrm{~J} / \mathrm{cm}^{2}$ and at 2 to $4 \mathrm{~Hz}$. The total $S$ signal obtained for pyrite was between 2-3 V. Under these conditions, after a $20 \mathrm{~s}$ baseline, $30 \mathrm{~s}$ of ablation is needed to obtain an internal ${ }^{34} S /{ }^{32} S$ precision of $\leq \pm 0.000005(2 \sigma)$. Two pyrite standards were used: PPP-1 (Gilbert et al., 2014) for external standard bracketing and the in-house standard Py2 for quality control of the analyses. The latter has previously been analyzed by gas mass spectrometry. Compared to the $\delta^{34} \mathrm{~S}-\mathrm{CDT}(\%)$ reference value of $-0.4 \pm 0.5 \%$ o $(1 \sigma)$, we obtained an average $\delta^{34} S$ value of $-0.3 \pm 0.2 \%$ $(2 \sigma, n=5)$ for the CDT standard. For more detailed information on the methods and conditions of the $\mathrm{S}$ and $\mathrm{Pb}$ isotope analyses, the reader is referred to Molnár et al. (2016a) and Molnár et al. (2016b), respectively.

In addition to in-situ sulfur isotope analyses, four whole-rock samples were analyzed for their sulfur isotope compositions at Iso-Analytical Limited in Cheshire, UK. Prior to analysis, each sample was milled to 125 microns. Sulfur isotope compositions were measured by an elemental analyzer/continuous flow isotopic ratio mass spectrometer (EA/IRMS). The samples were analyzed as duplicates, with the difference between each duplicate measurement varying from 0.15 to $1.3 \%$.

To assess to the source of dolomitic erratics occurring in the same shore area where sandstone boulders are found, we determined the carbon isotope composition of five dolomite samples at ISOLAB B.V. in Neerijnen, the Netherlands. Bulk 
carbon isotopes were analyzed using a Thermo Scientific Flash HT elemental analyzer coupled to a Thermo Scientific MAT 253 IRMS by a Thermo Scientific Conflo IV interface. The temperature of the reactor was kept at a constant temperature of $1020^{\circ} \mathrm{C}$. The samples were measured at least in triplicate and calibrated against two carbonate standards, with the analytical error being less than $\pm 0.2 \%$ o $(1 \sigma)$.

\section{Boulder types}

The sandstone boulders on the shore occur among a large variety of other boulder types including phyllites, porphyroblast-bearing mica schists, mica gneisses, porphyritic mafic rocks (uralite porphyrities), even-grained and porphyritic granitoids, metagabbros, metapyroxenites, conglomerates, finegrained quartzites (Fig. 4c), dolomites (Fig. 4a), amygdaloidal metabasalts (Fig. 4b), volcaniclastic rocks, and migmatites. The complexity of the glacial erratics is explained by the transport direction of continental ice sheet crossing the boundary between the SW margin of the Archean Karelia craton and the Svecofennian arc complex (Fig. 1), allowing the glacier to capture boulders from the Archean basement and its Paleoproterozoic cover rocks as well as Svecofennian granitoids and supracrustal rocks. Most of the boulders are rounded, longdistant travelers. Notable exceptions are large, angular boulders composed of very fine-grained and dark, non-schistose, occasionally concretionbearing mudstone with thin fractures filled with hematite, having an obvious local provenance, but whether they belong to the Precambrian bedrock or not, is so far unclear. There exist also rounded rusty boulders of mica schist or mica gneiss boulders with iron sulfides and some chalcopyrite (Fig. 4d), which may be mixed with sulfide-bearing sandstones. However, a closer look at their weathered or broken surface reveals their recrystallized and deformed nature and Precambrian age. It interesting to note that in spring 2018, one metapyroxenite boulder was found which contains around 7 wt.\% S and
1.0 wt. $\%$ of $\mathrm{Ni}+\mathrm{Cu}+\mathrm{Co}$. This indicates the presence of a mineralized mafic-ultramafic intrusion which likely belongs to the NW continuation of the $1.88 \mathrm{Ga}$ Kotalahti nickel belt (cf. Makkonen 2015).

Based on Makkonen (1971) and Niemelä (1983), Fig. 3 shows locations where sandstone boulders have been found on the shore and islands, extending to Piehinki, around $10 \mathrm{~km}$ to the south from Raahe. The southernmost sandstone boulders may be those mentioned by Veltheim (1969) that occur just north of the Pyhäjoki River, around $20 \mathrm{~km} \mathrm{SSW}$ of Raahe. The size of the sandstone boulders range from around $10 \mathrm{~cm}$ to $1.0 \mathrm{~m}$ and the form is rounded for the smallest ones but more angular and tabular for the largest ones (Figs. 4, 5). The weathering surface is grey (Fig. $5 \mathrm{a}$ ), brown or reddish brown (Figs. 4e, f) in color and often rugged, with light-colored quartz or feldspar crystals up to $1 \mathrm{~cm}$ in size standing up from the darker background in coarse-grained layers (Fig. 5a). Bedding and cross-bedding is visible in many boulders, with gravelly interbeds being from 1 to $-10 \mathrm{~cm}$ in thickness (Figs. 5a, c). Besides large quartz and feldspar grains, they also contain elongated or lens-like or angular, fine-grained, black or green lithic fragments (Fig. 5c).

For establishing the transportation direction of the glacial boulders, quartzites (Fig. 4c), carbonate rocks (Fig. 4a), and mafic amygdaloidal metabasalts are useful (Fig. 4b) because they are not typical Archean or Svecofennian rocks but rather resemble rock types found in Paleoproterozoic Karelian formations deposited on the Archean basement. In this case, the closest analogues of these boulders are found in the lower parts of the supracrustal sequences in the Kalix belt (e.g., Wanke \& Melezhik, 2005), the Peräpohja belt (Perttunen, 1985; Perttunen \& Hanski, 2003) and the Kiiminki belt (Honkamo, 1987) (Fig. 2). The mentioned boulder types occur along a strech of shore extending for around $20 \mathrm{~km}$ both to the south and north from Raahe. They are up to $0.5 \mathrm{~m}^{3}$ in size and generally rounded in form, indicating a long transportation distance. 
Figure 4. Different boulder types.

a) Carbonate rock.

b) Amygdaloidal

metabasalt.

c) Quartzite.

d) Sulfide-bearing

mica schist.

e) Sandstone.

f) Weakly

mineralized

sandstone.

Hammer head and

handle lengths

14 and $60 \mathrm{~cm}$,

respectively.
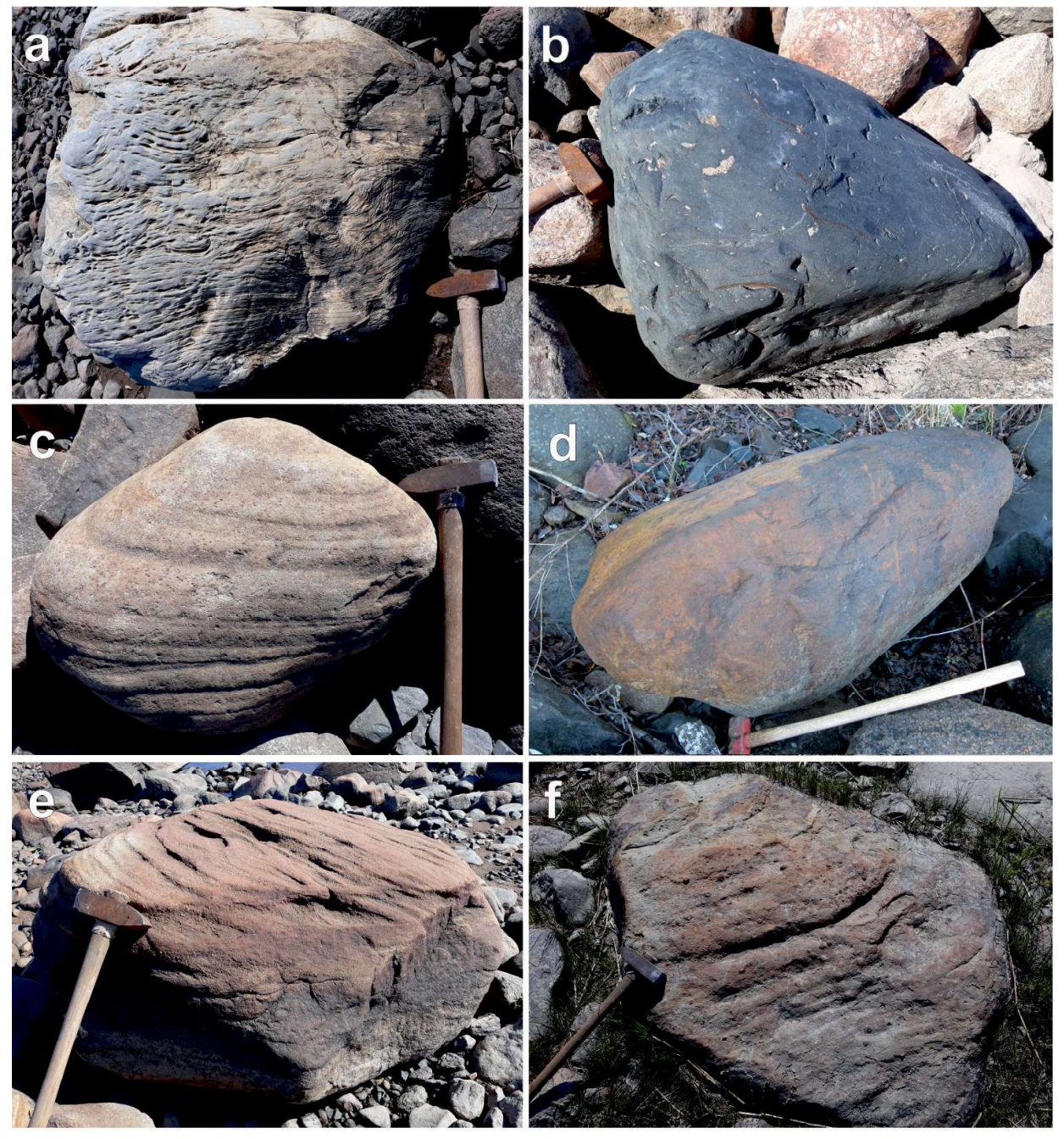

\section{Petrography and mineralogy}

The sandstone boulders are mature quartz-rich subarkoses with partially a matrix-supported clastic texture (Fig. 6a), indicating a large porosity of the original sediment. Detrital grains are mostly composed (around 85\%) of sub-rounded to rounded quartz accompanied with a lesser amount of feldspar. The latter is mainly potassium feldspar, with plagioclase being rare, which is also indicated by low bulk-rock $\mathrm{Na}_{2} \mathrm{O}$ contents of $<0.07$ wt. $\%$ (Table 1). The detritus commonly represent medium- to fine-grained sand (medium grain-size around $2.5 \mathrm{~mm}$ ), with larger quartz or feldspar grains up to $20 \mathrm{~mm}$ being found in coarser interbeds (Fig. 5c). Coarser sandstones typically show a bimodal grain-size distribution (Fig. 6c).

The cementing minerals are carbonate, opaque minerals and traces of barite and mica. The composition of the carbonate mineral was studied in one sample, where it turned out to be Fe-rich dolomite. In thin sections, the feldspar grains are commonly more irregular in form than the quartz grains, but in more coarse-grained interbeds, they often display euhedral forms (Fig. 6A). Resorption of detrital grains is commonly observed, especially when the grains are embedded in sulfides (Fig. 6d). 

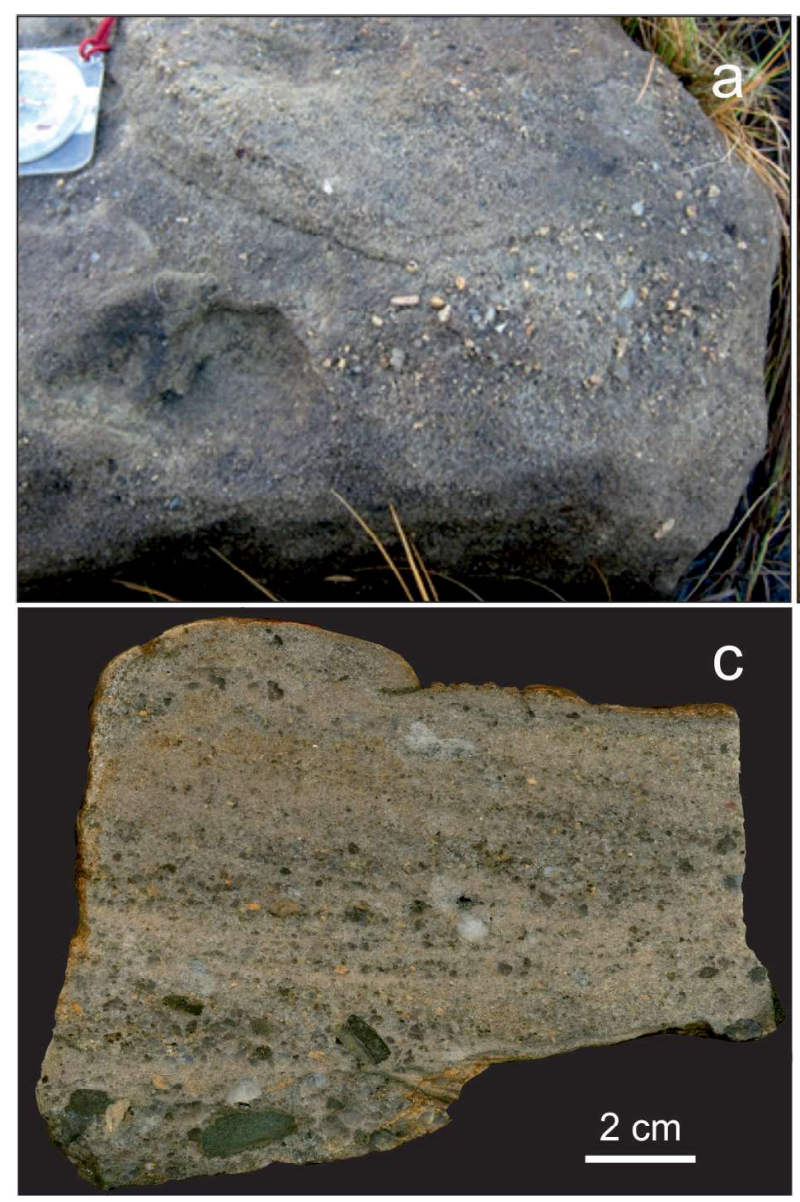

The ore mineral assemblages consist of sphalerite, galena, pyrite, marcasite, and chalcopyrite, but the proportions of these minerals vary widely. They can occur together, but the assemblage is often dominated either by sphalerite (Figs. 6a, d) or galena (Fig. 6c). In some cases, iron sulfide is most abundant, occurring as pyrite or marcasite (Fig. 6b) or both of them. Pyrite forms ovoidal or rounded concretions $1-2 \mathrm{~cm}$ in size. Also iron hydroxide (goethite) is locally found as an interstitial mineral. Ore minerals form often irregular or ameoboid $\mathrm{mm}$ - to $\mathrm{cm}$-sized patches (Fig. 6b), but galena and sphalerite also occur as more regular rounded clots, which are typical of the textures of the Laisvall ore (e.g., Rickard et al., 1979).

Sphalerite occurs in grains whose color shows a large variation from almost colorless through strawyellow to dark brown (Fig. 6a). It often shows color

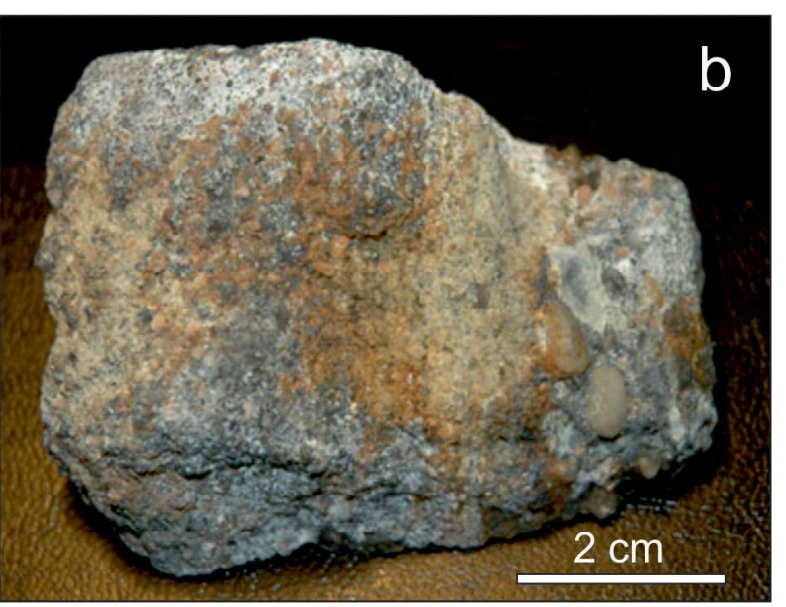

Figure 5. a) Non-mineralized boulder containing a more coarse-grained interbed with light-colored quartz and feldspar crystals. b) Hand specimen of coarse, mature mineralized sandstone containing a bed with up to pebble-sized quartz clasts (sample 73-511; Zn 10.1 wt.\%, Pb 2.1 wt.\%). c) Slab of non-mineralized sandstone boulder showing gravelly lag with crude cross-bedding and elongated greenish lithics at the bottom.

banding indicative of open-space crystallization and negligible degree of recrystallization. Commonly, the Fe content of sphalerite is a few wt.\%, though it may vary anywhere between 1 and 16 wt. $\%$. The lowest Fe contents were measured for colorless translucent sphalerite grains enclosed by galena, with their Fe falling down to 0.1 wt.\%. The differences in the $\mathrm{Fe}$ concentrations between the growth rings were not analyzed in detail but it seems that darker rings are higher in Fe. Compared to the composition of sphalerite at Laisvall, in which Fe commonly occurs at a level of less than 1.0 wt.\% (Saintilan et al., 2015a), the range of the $\mathrm{Fe}$ concentrations is rather high. Non-buffered sulfur fugacity in the studied rocks prevents the use of the Fe content of sphalerite as a geobarometer (Scott, 1976). Only trace amounts of other metals were measured, with the following 


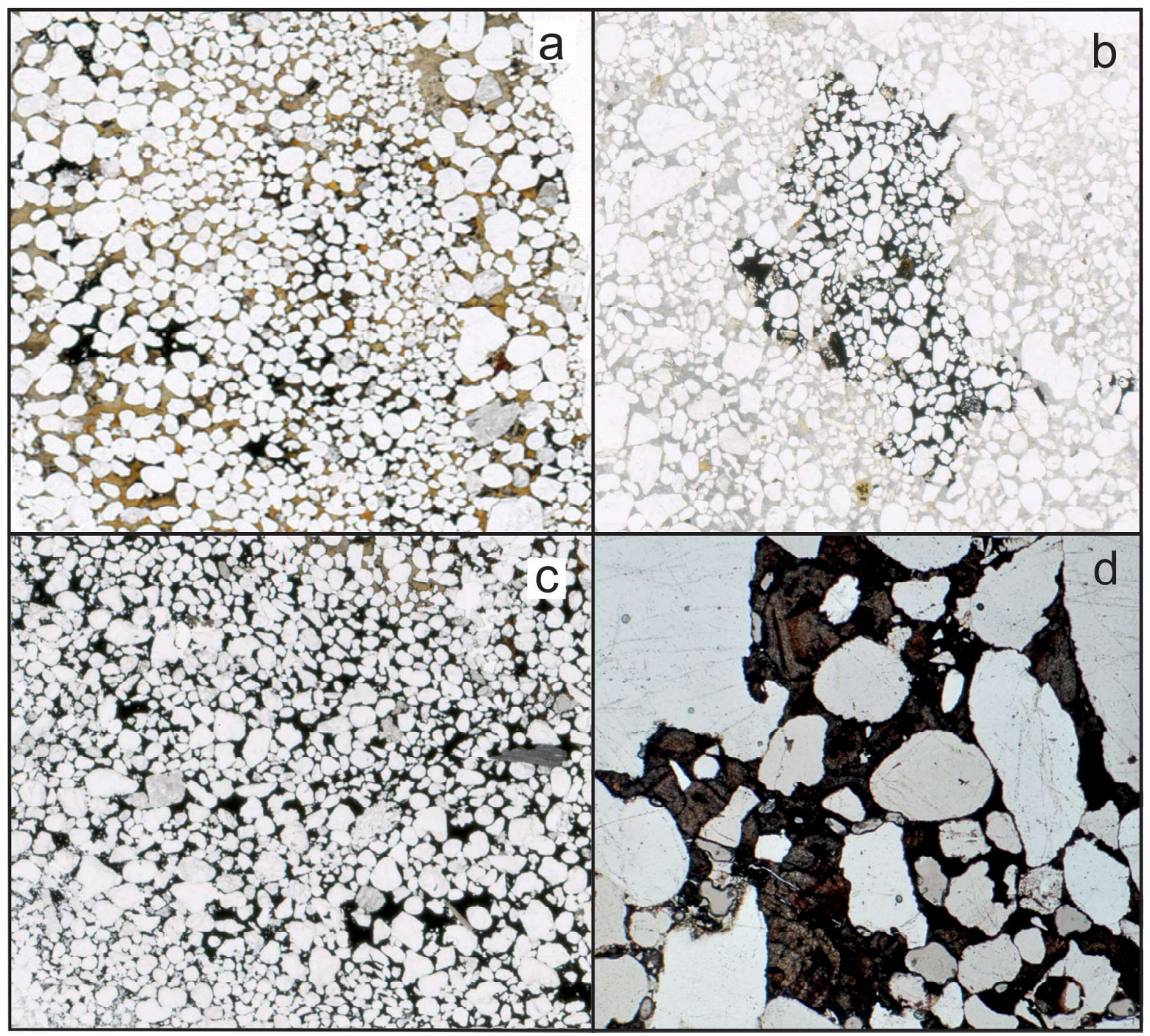

Figure 6. Sandstone textures. a) Scanned thin section of sphalerite-rich sandstone. b) Scanned thin section of carbonate- and marcasite-cemented sandstone. c) Scanned thin section of galena- and pyrite-rich sandstone. d) Photomicrograph of zoned sphalerite filling interstitial space between partly eroded detrital quartz grains. Transmitted light, parallel nicols.

average concentrations in wt.\%: Ga 0.05, Mn 0.01, Ag 0.01, As 0.02, Cu 0.13, Bi 0.01, In 0.01, and $\mathrm{Sb}$ 0.03. The most significant impurity is cadmium, which is also generally low (0.01-0.3 wt.\%) but in some sphalerite grains, may show values up to 3.3 wt.\%. The trace element systematics of sphalerite is similar to that at Laisvall (Saintilan et al., 2015a), but because of the low abundances, laser ablation analysis would be needed for a more detailed comparison.
Galena is very pure in the samples. The most abundant impurities are $\mathrm{Sb}$ and $\mathrm{Cd}$ occurring at levels of $0.1-0.2$ wt.\%. Excluding arsenic, the total amount of trace components in pyrite and marcasite is generally less than $0.2 \mathrm{wt} . \%$. In contrast, As can occur in concentrations ranging between zero to 3.8 wt.\%. Chalcopyrite is also close to its stoichiometric composition. The cumulative trace element contents rarely reach $0.5 \mathrm{wt} . \%$, with $\mathrm{Zn}$ being the most significant impurity. 
Table 1. Whole-rock and sulfur isotope compositions of mineralized sandstone boulders from the Raahe area.

\begin{tabular}{|lrrrrrrrrrrrrrrrrr|}
\hline & & 1 & 2 & 3 & 4 & 5 & 6 & 7 & 8 & 9 & 10 & 11 & 12 & 13 & 14 & 15 \\
\hline $\mathrm{S}$ & $\mathrm{wt} \%$ & 8.46 & 8.19 & 2.38 & 7.85 & 6.39 & 2.11 & 9.33 & 3.39 & 6.28 & $>10.0$ & 2.94 & 1.55 & 2.98 & 6.09 & $>10.0$ \\
$\mathrm{Fe}$ & $\mathrm{wt} \%$ & 4.36 & 2.10 & 4.35 & 8.56 & 1.97 & 7.56 & 5.82 & 4.87 & 3.29 & 16.00 & 5.83 & 4.47 & 3.74 & 6.96 & 13.65 \\
$\mathrm{~Pb}$ & $\mathrm{wt} \%$ & 3.92 & 3.48 & 0.34 & 8.57 & 1.79 & 0.28 & 1.08 & 5.43 & 0.71 & 0.01 & 0.03 & 4.02 & 6.98 & 1.69 & 0.02 \\
$\mathrm{Zn}$ & $\mathrm{wt} \%$ & 7.86 & 16.00 & 0.70 & 1.37 & 9.87 & 1.30 & 7.29 & 0.29 & 6.44 & 0.00 & 0.07 & 0.15 & 0.12 & 8.10 & 0.03 \\
$\mathrm{Cu}$ & $\mathrm{wt} \%$ & 3.42 & 0.01 & 0.00 & 0.49 & 0.02 & 0.02 & 0.95 & 0.07 & 0.31 & 4.02 & 0.02 & 0.04 & 0.09 & 0.00 & 4.47 \\
$\mathrm{Mn}$ & $\mathrm{wt} \%$ & 0.01 & 0.01 & 0.26 & 0.22 & 0.01 & 0.34 & 0.00 & 0.27 & 0.00 & 0.01 & 0.20 & 0.29 & 0.27 & 0.24 & 0.01 \\
$\mathrm{Ni}$ & $\mathrm{ppm}$ & 20 & 100 & 490 & 120 & 10 & 30 & 10 & 120 & 10 & 30 & 290 & 110 & 110 & 10 & 100 \\
$\mathrm{Co}$ & $\mathrm{ppm}$ & $<10$ & $<10$ & 260 & 110 & $<10$ & 20 & $<10$ & 280 & 10 & 30 & 290 & 110 & 230 & $<10$ & 60 \\
$\mathrm{As}$ & $\mathrm{ppm}$ & 50 & 350 & 1670 & 1040 & 280 & 210 & 520 & 2370 & 470 & 2510 & 1650 & 1150 & 1730 & 420 & 910 \\
$\mathrm{Mo}$ & $\mathrm{ppm}$ & 20 & 70 & $<10$ & 10 & 60 & 10 & 80 & 480 & 20 & $<10$ & 30 & 10 & 690 & 30 & $<10$ \\
$\mathrm{Ba}$ & $\mathrm{ppm}$ & 60 & 80 & 100 & 90 & 240 & 180 & 180 & $<50$ & 190 & 150 & 120 & 280 & 50 & $<50$ & 140 \\
$\mathrm{Cd}$ & $\mathrm{ppm}$ & 110 & 120 & $<10$ & 70 & 80 & $<10$ & 180 & 20 & 60 & $<10$ & $<10$ & 10 & 10 & 30 & $<10$ \\
$\mathrm{Cr}$ & $\mathrm{ppm}$ & 170 & 140 & 10 & 10 & 200 & 100 & 160 & 20 & 100 & 10 & 20 & 20 & 10 & 10 & 10 \\
$\mathrm{Ag}$ & $\mathrm{ppm}$ & 1 & 2 & $<1$ & 2 & 1 & 5 & 2 & 2 & $<1$ & 1 & $<1$ & $<1$ & 2 & $<1$ & 1 \\
$\mathrm{~J}^{34} \mathrm{SCDT}$ & $\% \%$ & 5.20 & -6.20 & -7.50 & 28.70 & n.a. & n.a. & n.a. & n.a. & n.a. & n.a. & n.a. & n.a. & n.a. & n.a. & n.a. \\
\hline
\end{tabular}

Sample codes: 1) 73-510, 2) 81-10570, 3) DAGB-127, 4) K/23369, 5) 73-511, 6) 76-1554, 7) 76-1555, 8) 81-10569A,

9) 82-10705, 10) 31-EJH-18, 11) 37-EJH-18, 12) 74-572, 13) 81-10569B, 14) K/23220, 15) K/23315

n.a. $=$ not analyzed

\section{Whole-rock chemistry}

\subsection{Sandstone boulders}

Examples of whole-rock metal and sulfur contents of sandstone boulders are listed in Table 1. Sandstone compositions obtained in this study together with those reported by Makkonen (1971), Saastamoinen (1981) and Niemelä (1983) and chemical data obtained from Pyhäsalmi Mine Oy are plotted in different diagrams in Figs. 7a-d. As a whole, metal concentrations show a very large variation. Zinc and lead vary from less than $1 \mathrm{wt} . \%$ to extreme values of more than $20 \mathrm{wt} . \%$ and $6 \mathrm{wt} . \%$, respectively. In the plot of $\mathrm{Zn}$ vs. Pb (Fig. 7a), two broad trends are seen, with one having high $\mathrm{Pb} / \mathrm{Zn}$ similar to that of a common Laisvall-type ore composition ( $\mathrm{Pb} / \mathrm{Zn} \mathrm{5-15;} \mathrm{Bjørlykke} \mathrm{\&}$ Thorpe, 1982) and the other showing Zn-dominant compositions with $\mathrm{Pb} / \mathrm{Zn}$ of $0.13-0.32$.

As shown in Fig. $7 \mathrm{~b}, \mathrm{Cu}$ concentrations are commonly low $(<0.2 \mathrm{wt} . \%)$, but in some cases, they attain levels of 1.0-2.7 wt.\% and rarely reach up to $7-8$ wt.\% or even $>10$ wt.\% (Makkonen, 1971). Copper shows a poor correlation with $\mathrm{Pb}$ or $\mathrm{Zn}$ as $\mathrm{Cu}$-rich samples are commonly low in $\mathrm{Pb}$ and $\mathrm{Zn}$. Particularly $\mathrm{Cu}$ and $\mathrm{Pb}$ seem to have an antipathetic relationship, as revealed by the ternary $\mathrm{Cu}-\mathrm{Zn}$-Pb diagram (Fig. 7d). Sulfur contents show a wide range from less than $1 \mathrm{wt} . \%$ up to $22 \mathrm{wt} . \%$. When total base metal contents are plotted against sulfur concentrations, a branched pattern appears, separating base metal sulfide-bearing samples from those dominated by iron sulfides (Fig. 7c). The minor components $\mathrm{Ni}$ and Co rarely occur in concentrations more than tens or hundreds of ppm, with their maximum amounts being 0.63 and 0.22 wt. \%, respectively. Arsenic varies from a few tens of ppm up to $>2000$ ppm. Two samples show relatively high Mo contents of 480 and 690 ppm, whereas in others, Mo occurs at a level from $<10$ to $80 \mathrm{ppm}$. The available silver data are scarce, showing mostly values of 2 ppm or less. 

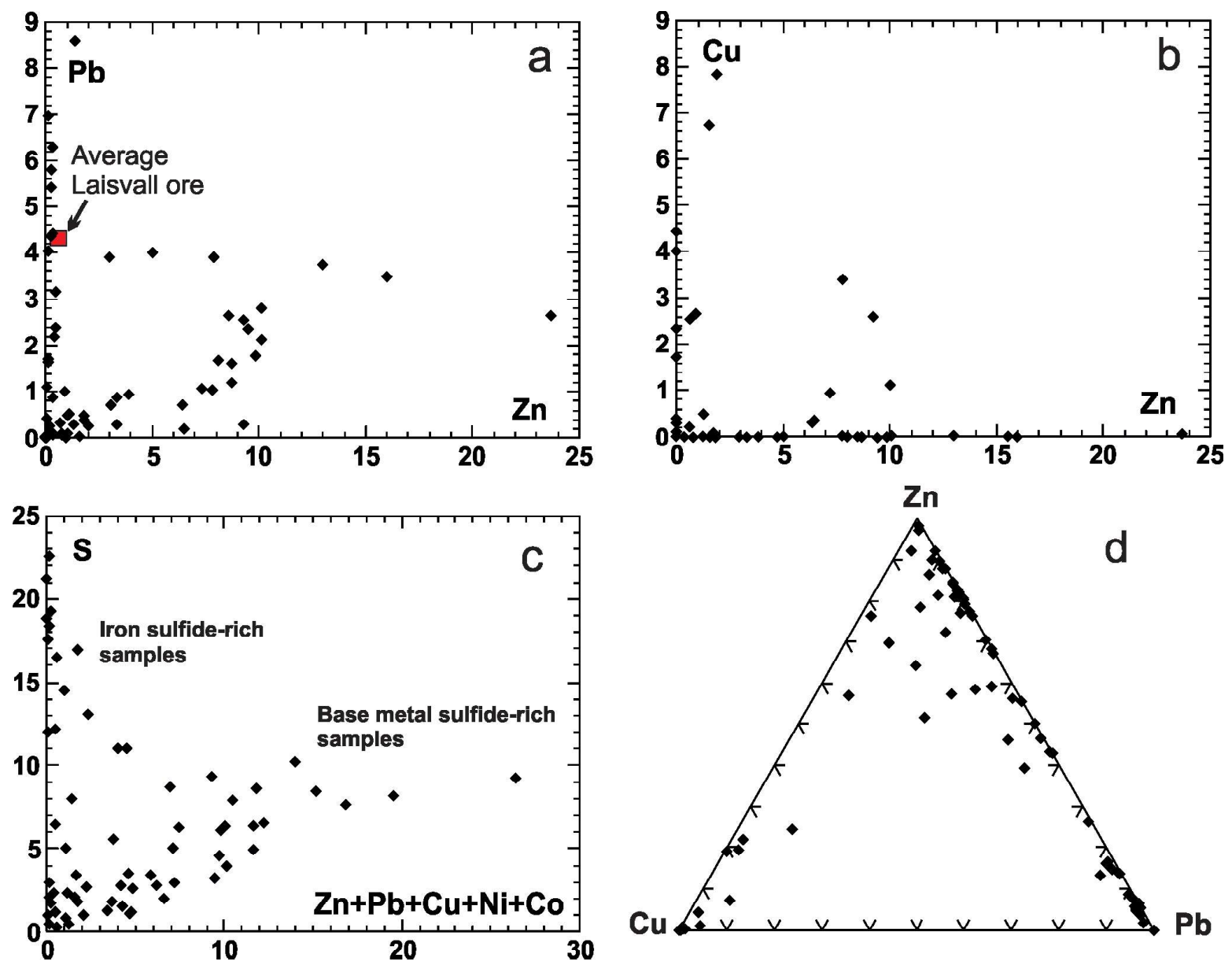

Figure 7. Whole-rock compositions of Raahe sandstone boulders (wt.\%). Data from this study and Makkonen (1971), Saastamoinen (1982), Niemelä (1983) and Pyhäsalmi Mine Oy (unpublished). An average Laisvall ore composition from Rickard et al. (1979) is shown in (a) for comparison. Because the Cu content is very low in Laisvall ore, Laisvall is not shown in other figures.

\subsection{Mafic metavolcanic boulders}

Four boulders of mafic amygdaloidal metavolcanite were analyzed for their major and trace elements. Results are presented in Table 2. All samples are very similar in their composition even though the samples were picked from a shore stretch of around $30 \mathrm{~km}$. This homogeneity implies that the boulders were derived from a similar source, potentially from a single volcanic unit.

The rocks can be classified as Fe-rich tholeiitic basalts. On trace element discrimination diagrams, such as the ternary Th-Hf/3-Nb/16 (Fig. 8b) or $\mathrm{Ti} / 100-\mathrm{Zr}-3 \mathrm{Y}$ plots (not shown), they are located in the field of N-MORB and MORB, respectively. Their chondrite-normalized REE patterns are rather flat, showing only a slight depletion in LREE compared to MREE (Fig. 8a). A slight positive spike at La may be attributed to postmagmatic mobility of this element. Trace elements signatures of the basaltic boulders do not reveal any features, such as low HFSE/LILE ratios, indicating crustal contamination. 

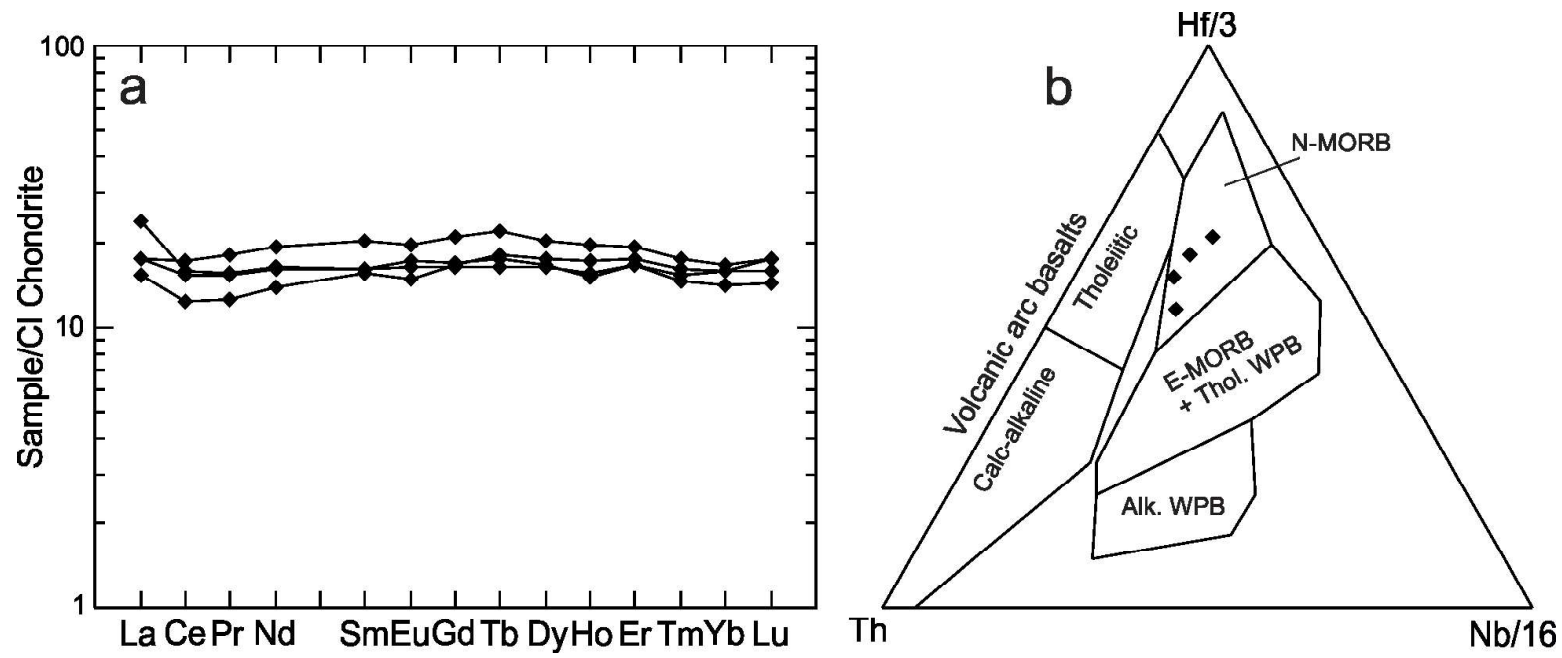

Figure 8. a) Chondrite-normalized REE diagram and b) Th-Hf/3-Nb/16 plot (after Wood, 1980) for glacial erratics of mafic metavolcanic rock in the Raahe area.

Table 2. Major and trace element compositions of boulders of mafic metavolcanic rock.

\begin{tabular}{|c|c|c|c|c|c|c|c|c|c|}
\hline & 1 & 2 & 3 & 4 & & 1 & 2 & 3 & 4 \\
\hline $\mathrm{SiO}_{2}$ & 48.01 & 49.4 & 47.47 & 47.1 & Sr & 45.8 & 57.9 & 50.4 & 38.8 \\
\hline $\mathrm{TiO}_{2}$ & 1.21 & 1.12 & 1.42 & 1.34 & $\mathbf{R b}$ & $<0.1$ & $<0.1$ & $<0.1$ & 0.5 \\
\hline $\mathrm{Al}_{2} \mathrm{O}_{3}$ & 14.06 & 13.38 & 13.65 & 14.64 & $\mathbf{N b}$ & 3.1 & 2.4 & 3.5 & 2.9 \\
\hline $\mathrm{Fe}_{2} \mathrm{O}_{3 \text { tot }}$ & 15.33 & 14.41 & 14.54 & 15.13 & Ta & 0.2 & 0.2 & 0.2 & 0.1 \\
\hline Mno & 0.27 & 0.26 & 0.28 & 0.23 & Th & 0.3 & $<0.2$ & 0.2 & 0.3 \\
\hline Mgo & 7.36 & 6.26 & 7.16 & 7.25 & $U$ & $<0.1$ & $<0.1$ & $<0.1$ & $<0.1$ \\
\hline $\mathrm{CaO}$ & 8.04 & 9.15 & 7.63 & 8.72 & La & 3.6 & 5.6 & 4.1 & 4.1 \\
\hline $\mathrm{Na}_{2} \mathrm{O}$ & 3.55 & 3.70 & 3.01 & 2.73 & $\mathrm{Ce}$ & 7.5 & 9.6 & 10.4 & 9.4 \\
\hline $\mathrm{K}_{2} \mathrm{O}$ & 0.11 & 0.11 & 0.03 & 0.16 & $\operatorname{Pr}$ & 1.18 & 1.47 & 1.72 & 1.44 \\
\hline $\mathbf{P}_{2} \mathbf{O}_{5}$ & 0.09 & 0.06 & 0.10 & 0.08 & Nd & 6.4 & 7.6 & 9.0 & 7.5 \\
\hline LOI & 1.85 & 3.04 & 4.34 & 2.53 & Sm & 2.36 & 2.45 & 3.09 & 2.46 \\
\hline \multirow[t]{2}{*}{ Total } & 99.88 & 100.9 & 99.63 & 99.91 & $\mathrm{Eu}$ & 0.85 & 0.95 & 1.14 & 0.99 \\
\hline & & & & & Gd & 3.40 & 3.35 & 4.29 & 3.43 \\
\hline Cr & 191.6 & 205.3 & 212.1 & 219.0 & Tb & 0.67 & 0.61 & 0.82 & 0.65 \\
\hline $\mathrm{Ni}$ & 102 & 90 & 102 & 94 & Dy & 4.44 & 4.11 & 5.15 & 4.21 \\
\hline $\mathbf{v}$ & 340 & 322 & 314 & 339 & Ho & 0.97 & 0.88 & 1.11 & 0.85 \\
\hline Co & 50.6 & 46.6 & 48.2 & 46.2 & Er & 2.86 & 2.72 & 3.19 & 2.73 \\
\hline Sc & 47 & 43 & 40 & 44 & $\mathrm{Tm}$ & 0.41 & 0.37 & 0.44 & 0.39 \\
\hline $\mathrm{Zr}$ & 64.9 & 59.7 & 81.5 & 72.9 & $\mathrm{Yb}$ & 2.66 & 2.40 & 2.82 & 2.68 \\
\hline Hf & 1.7 & 1.8 & 2.5 & 2.1 & Lu & 0.44 & 0.36 & 0.44 & 0.40 \\
\hline $\mathrm{Ba}$ & 21 & 15 & 3 & 25 & $\mathbf{Y}$ & 26.0 & 22.6 & 28.7 & 23.6 \\
\hline
\end{tabular}




\section{Isotope geochemistry}

\section{1. $\mathrm{Pb}-\mathrm{Pb}$ isotopes}

Four samples, 73-510, 73-511, 81-10570 and 82-10705, were selected for $\mathrm{Pb}-\mathrm{Pb}$ isotope analysis by laser ablation ICP-MS. These samples are of interest because of their high metal contents, with up to 16 wt. $\% \mathrm{Zn}, 4.0$ wt. $\% \mathrm{~Pb}$ and 3.4 wt. $\% \mathrm{Cu}$ (Table 1). The average of lead isotope compositions of these samples and one standard sample are listed in Table 3, and results of individual laser ablation analyses are plotted on ${ }^{207} \mathrm{~Pb} /{ }^{204} \mathrm{~Pb}$ vs. ${ }^{206} \mathrm{~Pb} / 204 \mathrm{~Pb}$ and ${ }^{208} \mathrm{~Pb} /{ }^{204} \mathrm{~Pb}$ vs. ${ }^{206} \mathrm{~Pb} /{ }^{204} \mathrm{~Pb}$ diagrams in Figs.
$9 \mathrm{a}$ and $9 \mathrm{~b}$, respectively, with $2 \sigma$ error bars shown for each spot analysis and error envelopes for each sample. Note that the data are presented at a very detailed scale to display all the points properly. On the ${ }^{207} \mathrm{~Pb} /{ }^{204} \mathrm{~Pb}$ vs. ${ }^{206} \mathrm{~Pb} /{ }^{204} \mathrm{~Pb}$ graph (Fig. 9a), only sample 82-705 is distinct from the others. However, on the ${ }^{208} \mathrm{~Pb} /{ }^{204} \mathrm{~Pb}$ vs. ${ }^{206} \mathrm{~Pb} /{ }^{204} \mathrm{~Pb}$ graph (Fig. 9b), the inter-sample range in ${ }^{208} \mathrm{~Pb} /{ }^{204} \mathrm{~Pb}$ compared to ${ }^{207} \mathrm{~Pb} /{ }^{204} \mathrm{~Pb}$ is larger $(0.9 \%$ versus $0.3 \%)$ requiring a coarser scale to plot all of the points. Due to this wider range in ${ }^{208} \mathrm{~Pb} / 204 \mathrm{~Pb}$, there is an apparent linear relationship among the compositions of the samples, potentially suggesting some type of mixing line.

Table 3. Lead isotope data for galena from Raahe sandstone boulders. In-situ LA-ICP-MS data (averages of several grains) from this study, TIMS data by Matti Vaasjoki (GTK, Espoo).

\begin{tabular}{|llllllll|}
\hline Sample & ${ }^{206} \mathbf{P b} /{ }^{204} \mathbf{P b}$ & $\mathbf{2 \sigma} \%$ & ${ }^{207} \mathbf{P b} /{ }^{204} \mathbf{P b}$ & $\mathbf{2 \sigma} \%$ & ${ }^{208} \mathbf{P b} /{ }^{204} \mathbf{P b}$ & $\mathbf{2 \sigma} \%$ & \# of anal. \\
\hline LA-MC-ICPMS data & & & & & & & \\
\hline $81-10570$ & 21.032 & 0.04 & 15.945 & 0.03 & 40.012 & 0.04 & $\mathrm{n}=3$ \\
$82-705$ & 20.575 & 0.20 & 15.904 & 0.03 & 39.762 & 0.06 & $\mathrm{n}=5$ \\
$73-510$ & 20.942 & 0.20 & 15.927 & 0.10 & 39.961 & 0.11 & $\mathrm{n}=6$ \\
$73-511$ & 21.033 & 0.18 & 15.931 & 0.08 & 40.064 & 0.09 & $\mathrm{n}=6$ \\
Standard & & & & & & & \\
GPG1 & 13.941 & 0.18 & 14.753 & 0.15 & 33.712 & 0.16 & $\mathrm{n}=8$ \\
\hline TIMS data & & & & & & & \\
\hline G486/1 & 21.002 & 0.12 & 15.955 & 0.12 & 40.117 & 0.12 & \\
G486/2 & 21.140 & 0.12 & 15.973 & 0.12 & 40.244 & 0.12 & \\
G487/1 & 21.487 & 0.12 & 16.035 & 0.12 & 40.240 & 0.12 & \\
G487/2 & 21.543 & 0.12 & 16.041 & 0.12 & 40.272 & 0.12 & \\
G488/1 & 20.469 & 0.12 & 15.906 & 0.12 & 39.713 & 0.12 & \\
G488/2 & 21.821 & 0.12 & 16.105 & 0.12 & 40.364 & 0.12 & \\
G066a & 21.028 & 0.12 & 15.930 & 0.12 & 39.973 & 0.12 & \\
G066b & 20.941 & 0.12 & 15.952 & 0.12 & 39.992 & 0.12 & \\
G067a & 21.037 & 0.12 & 15.954 & 0.12 & 40.089 & 0.12 & \\
G067b & 21.109 & 0.12 & 15.959 & 0.12 & 40.168 & 0.12 & \\
\hline
\end{tabular}



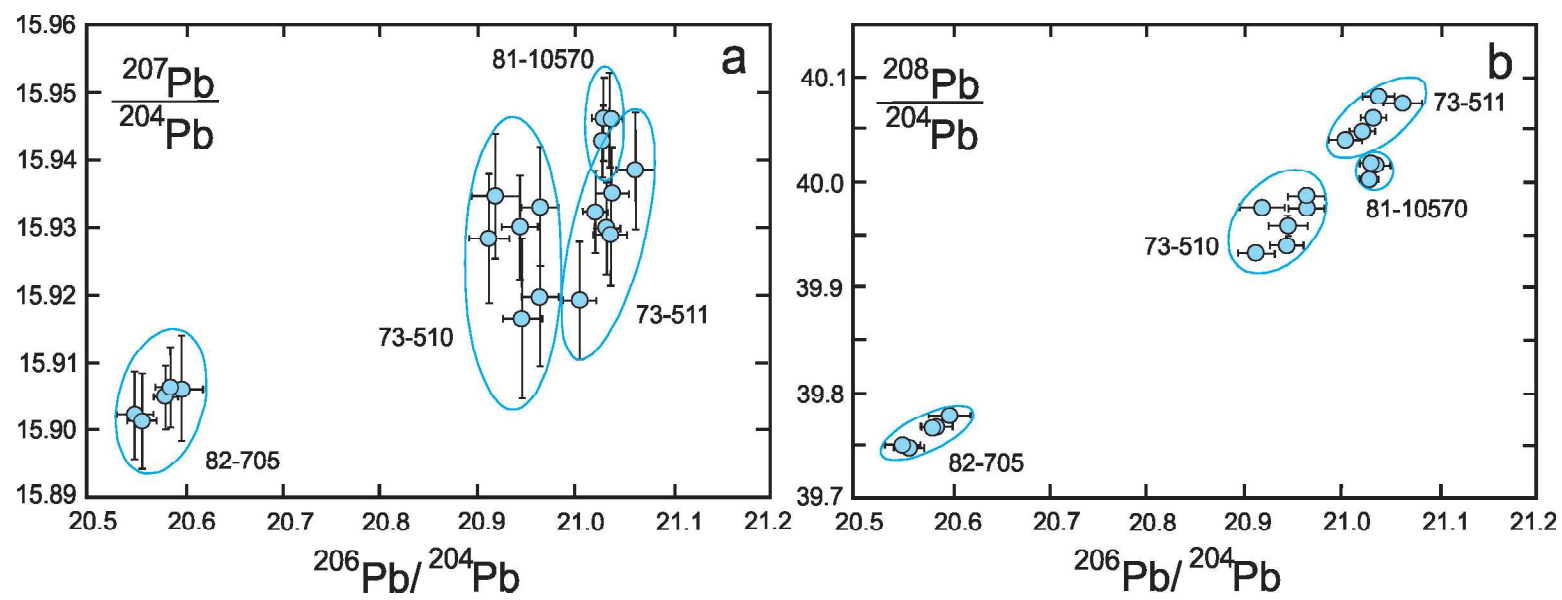

Figure 9. ${ }^{207} \mathrm{~Pb} /{ }^{204} \mathrm{~Pb}$ vs. ${ }^{206} \mathrm{~Pb} /{ }^{204} \mathrm{~Pb}$ and ${ }^{208} \mathrm{~Pb} /{ }^{204} \mathrm{~Pb}$ vs. ${ }^{206} \mathrm{~Pb} /{ }^{204} \mathrm{~Pb}$ diagrams presenting laser ablation isotope data for galena in Raahe boulders, with 2 sigma error bars and error envelopes shown for each sample. ${ }^{207} \mathrm{~Pb} /{ }^{204} \mathrm{~Pb}$ data for each sample are within $2 \sigma$ of the measurements, but ${ }^{206} \mathrm{~Pb} /{ }^{204} \mathrm{~Pb}$ and ${ }^{208} \mathrm{~Pb} /{ }^{204} \mathrm{~Pb}$ variability is larger than $2 \sigma$ suggesting that there is measurable isotopic grain to grain variability in these two ratios in all 4 samples.

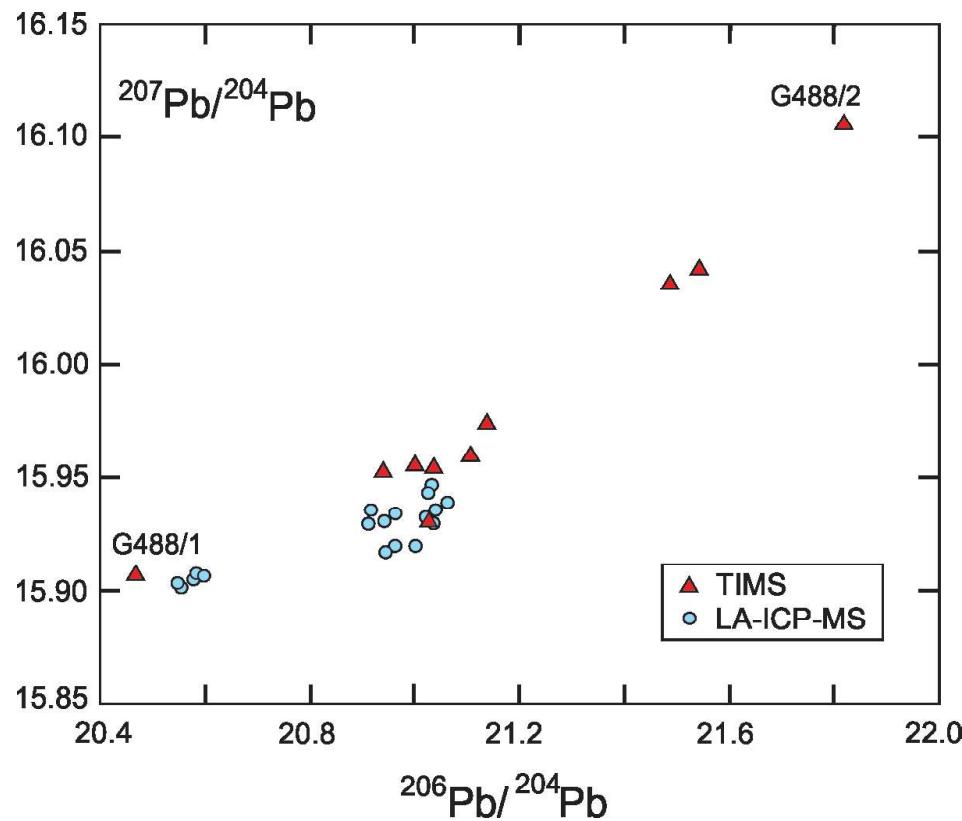

Figure 10. ${ }^{207} \mathrm{~Pb} /{ }^{204} \mathrm{~Pb}$ vs. ${ }^{206} \mathrm{~Pb} /{ }^{204} \mathrm{~Pb}$ diagram comparing LA-ICP-MS (blue) and TIMS isotope (red) data for galena in Raahe boulders. Analytical uncertainties ignored (shown in Table 3 and Fig. 9).

In addition to LA-ICP-MS data, we utilize the analytical results obtained by Matti Vaasjoki in the 1990s for galena from 5 samples using thermal ionization mass spectrometry (TIMS) (Table 3). When all available lead isotope data are plotted in ${ }^{207} \mathrm{~Pb} /{ }^{204} \mathrm{~Pb}-{ }^{206} \mathrm{~Pb} /{ }^{204} \mathrm{~Pb}$ and ${ }^{208} \mathrm{~Pb} /{ }^{204} \mathrm{~Pb}-{ }^{206} \mathrm{~Pb} /{ }^{204} \mathrm{~Pb}$ compositional space (Fig. 10), the degree of clustering of the LA-ICP-MS and TIMS data is readily apparent. In particular, the 2 subsamples from G488 (hand-picked galena grains, dissolved and run by TIMS) show a very wide variation in composition. Such a large variation cannot be attributed to analytical effects and therefore demonstrates true inhomogeneity in the sample. 
Table 4. In-situ sulfur isotope compositions of pyrite and marcasite.

\begin{tabular}{|c|c|c|c|c|c|c|c|c|}
\hline Sample & Mineral & $\delta^{34} S \%{ }_{0}$ CDT & $2 \sigma$ & Note & Sample & Mineral & $\delta^{34} S \%{ }^{2}$ CDT & $2 \sigma$ \\
\hline 24-EAN-15 & Pyrite & -15.6 & 0.1 & & K/23315 & Pyrite & -33.9 & 0.09 \\
\hline 24-EAN-16 & Pyrite & -12.8 & 0.2 & & K/23315 & Pyrite & -30.0 & 0.10 \\
\hline 24-EAN-17 & Pyrite & -9.4 & 0.1 & & K/23315 & Pyrite & -31.0 & 0.09 \\
\hline 24-EAN-18 & Pyrite & -11.6 & 0.1 & & K/23315 & Pyrite & -31.2 & 0.09 \\
\hline 24-EAN-19 & Pyrite & -10.3 & 0.2 & & K/23315 & Pyrite & -36.4 & 0.09 \\
\hline 24-EAN-20 & Pyrite & -13.0 & 0.1 & & $82-10705$ & Pyrite & -35.7 & 0.11 \\
\hline 6-EAN-15 & Pyrite & -10.1 & 0.1 & core & $82-10705$ & Pyrite & -26.2 & 0.08 \\
\hline 6-EAN-16 & Pyrite & -9.4 & 0.1 & rim & $82-10705$ & Pyrite & -27.1 & 0.09 \\
\hline 6-EAN-17 & Pyrite & -7.6 & 0.1 & core & $82-10705$ & Pyrite & -27.4 & 0.09 \\
\hline 6-EAN-18 & Pyrite & -0.3 & 0.1 & core & $82-10705$ & Pyrite & -27.1 & 0.08 \\
\hline 6-EAN-19 & Pyrite & -3.3 & 0.1 & rim & 25-EAN-15 & Marcasite & -0.5 & 0.11 \\
\hline 6-EAN-20 & Pyrite & 6.7 & 0.1 & rim & 25-EAN-15 & Marcasite & -1.0 & 0.11 \\
\hline 6-EAN-21 & Pyrite & -13.4 & 0.1 & core & 25-EAN-15 & Marcasite & -0.7 & 0.10 \\
\hline 6-EAN-22 & Pyrite & -14.4 & 0.1 & core & 25-EAN-15 & Marcasite & -0.6 & 0.08 \\
\hline 6-EAN-23 & Pyrite & -10.0 & 0.1 & core & 25-EAN-15 & Marcasite & -0.4 & 0.09 \\
\hline 6 -EAN-24 & Pyrite & -13.6 & 0.1 & core & & & & \\
\hline
\end{tabular}

\subsection{Sulfur isotopes}

Five samples were selected for in-situ sulfur isotope analysis of pyrite and marcasite. Results are shown in Fig. 11a and listed in Table 4. With the exception of one positive value $\left(\delta^{34} S+6.7\right), \delta^{34} S(\mathrm{CDT})$ values for pyrite from 4 samples are all negative with a large range from -36.4 to $-0.3 \%$. Intra-sample spread is from 6 to $9 \delta^{34} \mathrm{~S}$ units in 3 samples whereas in one sample, it is much larger, 21 units. In the latter sample, which has the heaviest sulfur isotope composition, a single pyrite grain shows a $\delta^{34} \mathrm{~S}$ variation from -3.3 to $+6.7 \%$. A more detailed study would be needed to elucidate the mineral-and sample-scale $S$ isotopic heterogeneity. Nevertheless, as shown in Fig. 11a, most pyrite compositions seem to be light with a rough bimodal distribution clustering around $-30 \%$ and $-11 \%$. Marcasite was only analyzed from one sample, yielding $\delta^{34} S$ values from -1.0 to $-0.4 \%$ (Table 3 ).
Sulfur isotope compositions were also determined for 4 bulk-rock samples of mineralized sandstone. The isotope compositions and corresponding whole-rock metal contents are reported in Table 1. The $\delta^{34} S$ values are highly variable, falling in the range from -7.2 to $+28.7 \%$. Based on the limited amount of data available so far, there seems to be no clear correlation between the metal content and $\delta^{34} S$ in the samples (Table 1 ), though the heaviest $S$ occurs in the sample that is richest in $\mathrm{Pb}$, indicating the presence of similarly heavy galena as at Laisvall (Saintilan et al., 2016).

\subsection{Carbon isotopes}

Five dolomite boulder samples analyzed for their carbon isotope compositions yielded the following $\delta^{13} \mathrm{C}$ values (per mil deviation relative to the Pee Dee Belemnite standard): $+2.3,+3.1,+3.5,+3.6$, and $+5.1 \%$ o (Fig. 12). These ${ }^{13} \mathrm{C}$-enriched compositions 

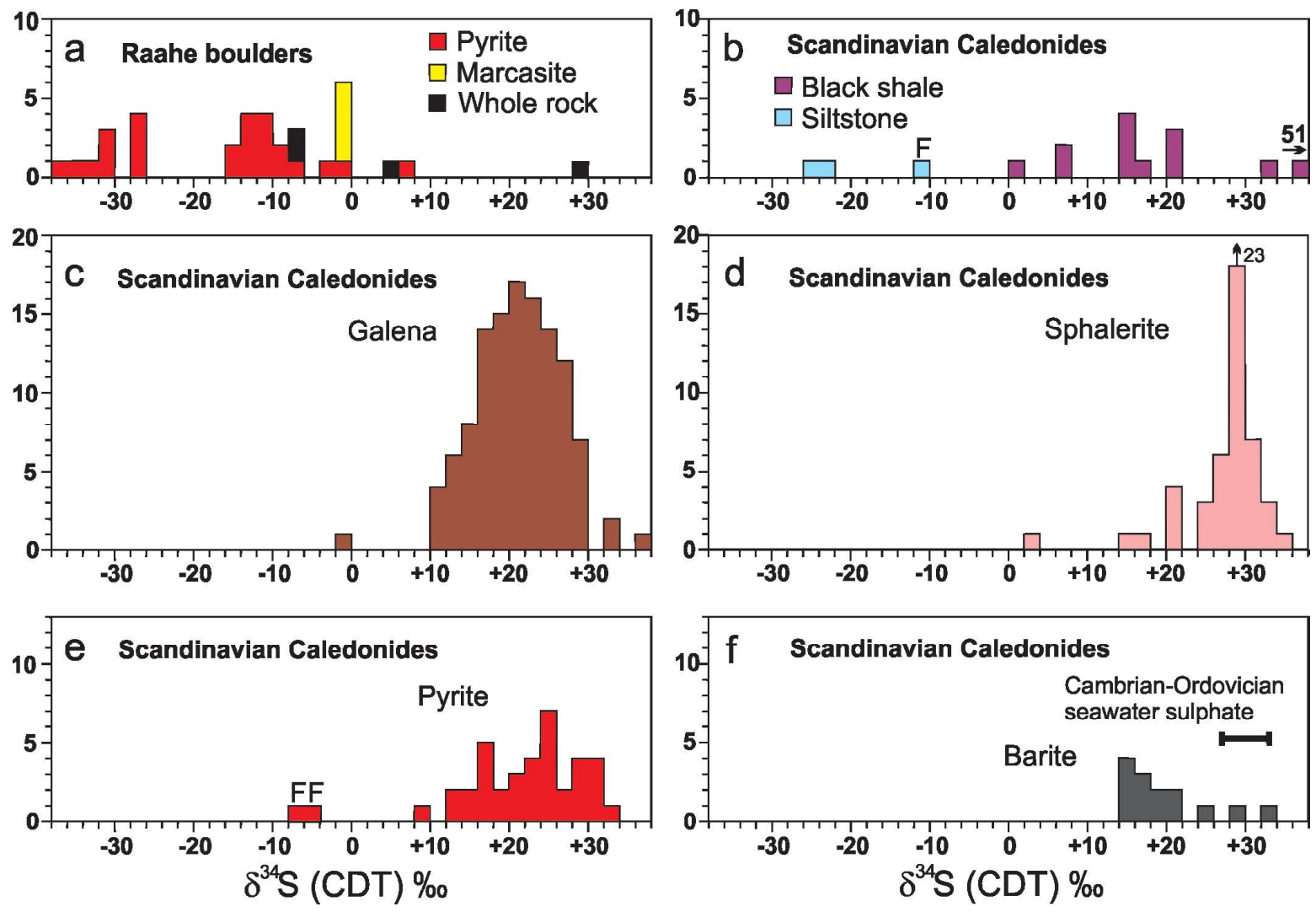

Figure 11. Frequency diagrams for sulfur isotope composition in sulfides and sulfates from Raahe boulders and the Laisvall and Vassbo deposits and their country rocks. a) Raahe boulders: pyrite and marcasite (in-situ analyses) and bulk rock. b) Pyrite from siltstone in the Grammajukku Formation at Laisvall and siltstone at Osen and black shales (Alum Shale) at Laisvall and Osen, all overlying mineralized sandstones in the stratigraphy (Rickard et al., 1979; Bjørlykke, 1983; Saintilan et al., 2016). c-f) Galena, sphalerite, pyrite and barite from Paleozoic sandstone-hosted $\mathrm{Pb}-\mathrm{Zn}$ mineralization in the Caledonian front in Sweden (Laisvall and Vassbo; Rickard et al., 1979, 1981; Saintilan et al., 2016) and southern Norway (Osen, Gjøvik and Galåa; Bjørlykke, 1983). The two pyrite samples with negative $\delta^{34} \mathrm{~S}$ from the Caledonides that are marked by letter $\mathrm{F}$ (Fig. 11e) represent framboidal pyrite formed before the $\mathrm{Pb}-\mathrm{Zn}$ mineralization. Similarly, one framboidal pyrite among the Grammajukku Formation samples is marked by letter $\mathrm{f}$ (Fig. 11b).

match well with the heavy carbon isotope anomaly attributed to the Lomagundi-Jatuli event. This event is recorded by a shield-wide occurrence of heavy carbon isotope compositions with $\delta^{13} \mathrm{C}$ up to +18 measured for marine carbonate sediments that were deposited at a time interval of ca. 2.3-2.06 Ga (Karhu, 2005; Melezhik et al., 2013), including carbonate rocks in the Kalix greenstone belt in Sweden (Melezhik \& Fallick, 2010) (Fig. 12). 


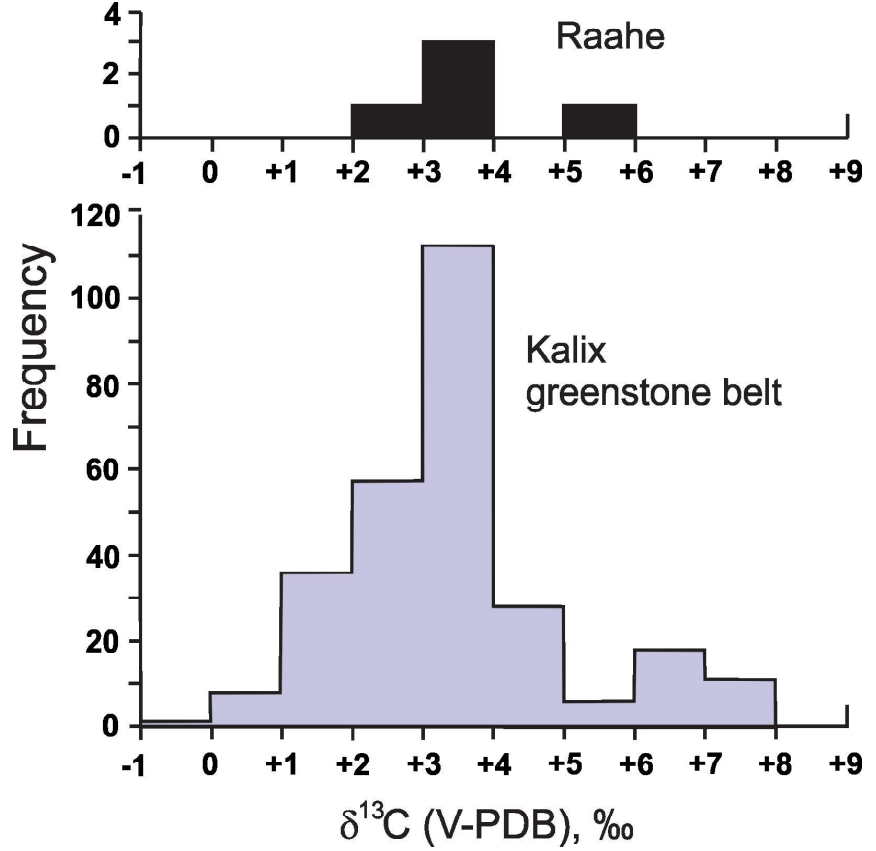

Figure 12. $\delta^{13} \mathrm{C}$ histograms comparing glacial dolomite erratics from the Raahe area with dolomite samples from the Kalix greenstone, Sweden. Positive $\delta^{13} \mathrm{C}$ values indicate moderately heavy carbon isotope compositions consistent with the JatuliLomagundi carbon isotope excursion. Kalix data taken from Melezhik et al. (2013).

\section{Discussion}

\subsection{Source of metals and timing of the mineralization event}

A characteristic feature of the sandstone-hosted Laisvall-type deposits in Sweden and Norway is the strongly radiogenic composition of galena (e.g., Bjørlykke \& Thorpe, 1982; Johansson \& Rickard, 1984; Romer, 1992). In Figs. 13a-b, lead isotope data obtained for galena from Raahe boulders are compared with isotope data of galena in four Paleozoic sandstone-hosted $\mathrm{Pb}-\mathrm{Zn}$ deposits from the Caledonian front, i.e. Laisvall, Vassbo, Osen, and Dorotea (for their locations, see Fig. 1). The similarity both in the uranogenic and thorogenic lead isotope compositions between Raahe and three of the four reference deposits is striking, with only the Dorotea deposit having slightly more radiogenic lead. Although $\mathrm{Pb}$ isotope data cannot be used to calculate true measured ages for the sandstonehosted mineralization in Raahe boulders, their $\mathrm{Pb}$ isotope compositions, which overlap with those of the Paleozoic sandstone-hosted deposits in Sweden and Norway, strongly suggest a similar timing of the mineralization processes and a similar history of the lead in their galena.

Figure 14 shows a ${ }^{207} \mathrm{~Pb} /{ }^{204} \mathrm{~Pb}$ vs. ${ }^{206} \mathrm{~Pb} /{ }^{204} \mathrm{~Pb}$ plot where the Raahe $\mathrm{Pb}$ isotope data are compared with Phanerozoic lead from the Caledonian front, including galena compositions from sandstonehosted $\mathrm{Pb}-\mathrm{Zn}$ deposits and sulfide-bearing quartz and calcite veins. Galena- and sphalerite-bearing calcite veins occur in the Precambrian basement close to the erosional border of the Caledonides or in basement windows within the Caledonides, and their genesis is regarded to be related to the processes that generated sandstone-hosted impregnation ore in the overlying Paleozoic sediments (Johansson, 1983). Sulfide-bearing quartz veins are also found within the Caledonides, particularly in the vicinity of basement windows, but their occurrence is more versatile than that of calcite veins, being located at several structural levels from the basement to highest nappe units (Johansson, 1983). As shown in Fig. 14, the Phanerozoic galena compositions are variably radiogenic, displaying an almost continuous linear array, the so-called "Phanerozoic 

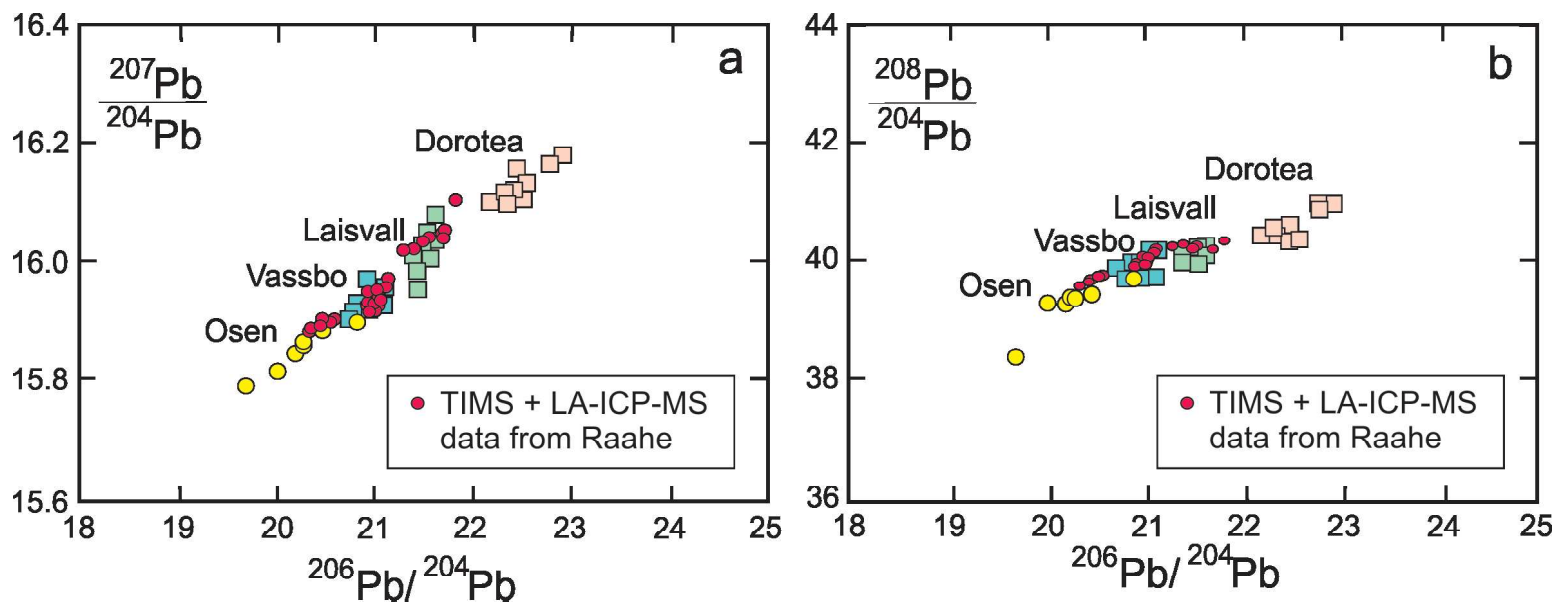

Figure 13. Pb isotope composition of galena in Raahe boulders and four Laisvall-type sandstone-hosted Pb-Zn deposits, Laisvall, Vassbo and Dorotea in Sweden and Osen in Norway (for their location, see Fig. 1). Reference data taken from Rickard et al. (1981), Bjørlykke and Thorpe (1982), Johansson and Rickard (1984), and Schweda and Johansson (1984).

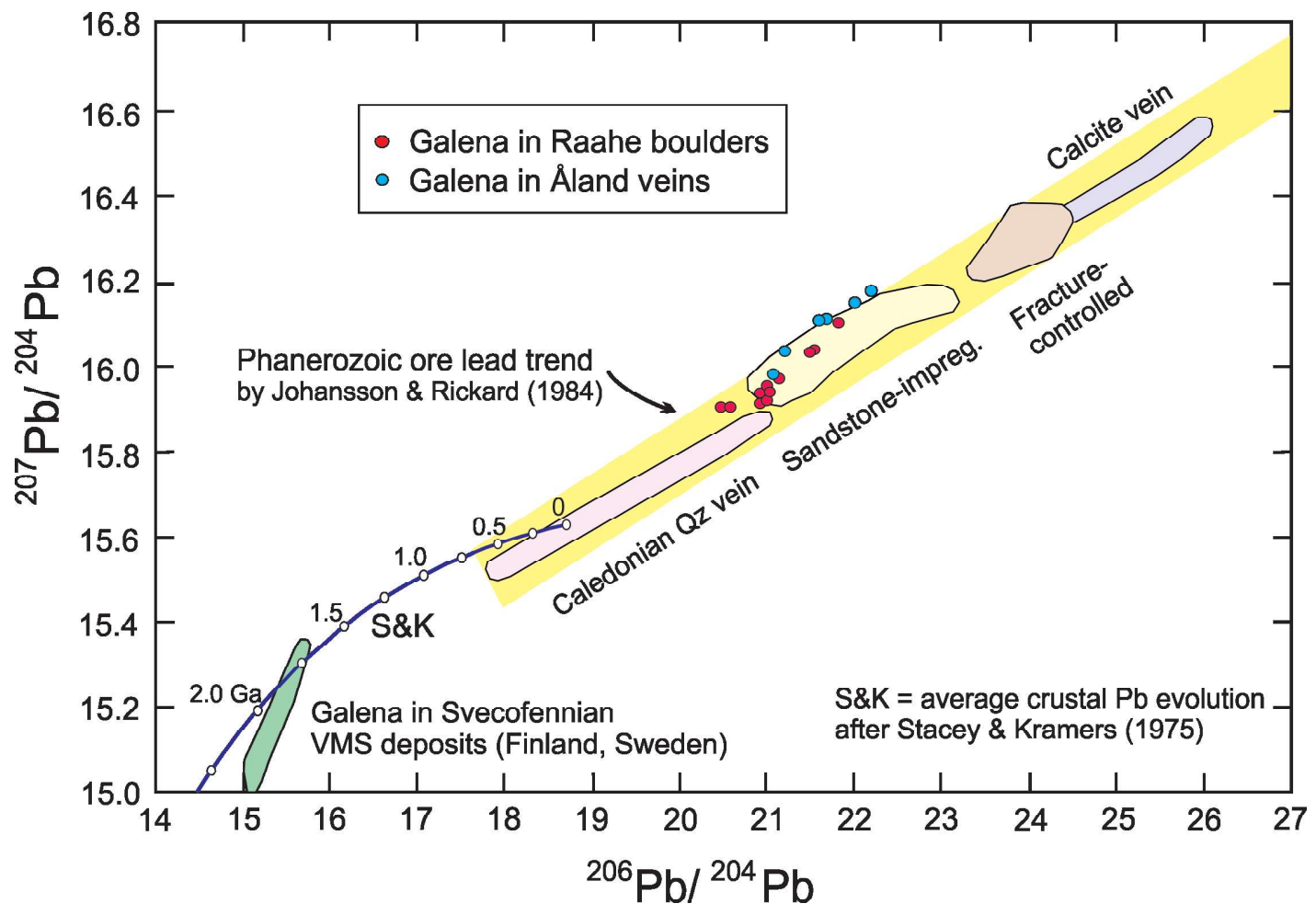

Figure 14. ${ }^{207} \mathrm{~Pb} /{ }^{204} \mathrm{~Pb}$ vs. ${ }^{206} \mathrm{~Pb} /{ }^{204} \mathrm{~Pb}$ plot comparing galena isotope compositions of Raahe boulders and Åland veins with those of Phanerozoic ore leads. Åland data taken from Vaasjoki (1977). The yellow band represents the "Phanerozoic ore lead trend" defined by Johansson and Rickard (1984), which includes fields of sulfide-bearing quartz veins, sandstone-hosted $\mathrm{Pb}-\mathrm{Zn}$ deposits, fracture-controlled $\mathrm{Zn}-\mathrm{Pb}$ mineralization, and sulfide-bearing calcite veins (after Johansson, 1983, and Billström et al., 2012). For comparison, also shown are the average crustal Pb growth curve of Stacey and Kramers (1975) (blue line, S\&K) and isotope data from Svecofennian VMS deposits (Vaasjoki, 1981, 1989; Rickard \& Svensson, 1984; Johansson \& Rickard, 1985; Hallberg, 1989; Vaasjoki \& Vivallo, 1990; Billström \& Vivallo, 1994). 
ore lead trend" of Johansson and Rickard (1984), on which the galena compositions of Raahe boulders also plot. Galena has also been analyzed from calcite veins that occur in Åland (Vaasjoki, 1977), being radiogenic in a similar way to the Raahe galena though having slightly higher ${ }^{207} \mathrm{~Pb} /{ }^{206} \mathrm{~Pb}$ (Fig. 14).

For comparison, Fig. 14 also shows a field for galena from Svecofennian VMS-type base metal deposits from both sides of the Bothnian Bay, including Vihanti and Pyhäsalmi in Finland (e.g., Mäki et al., 2015) and the deposits of the Skellefte district in Sweden (e.g., Billström \& Weihed, 1996) (see Fig. 1). Galena in these deposits shows a nonradiogenic $\mathrm{Pb}$ isotope composition, with ${ }^{206} \mathrm{~Pb} /{ }^{204} \mathrm{~Pb}$ being always $<15.8$ and ${ }^{207} \mathrm{~Pb} /{ }^{204} \mathrm{~Pb}$ $<15.4$ (Fig. 14). It would therefore be easy to recognize this kind of lead if it had been mobilized in Phanerozoic time from Svecofennian $\mathrm{Pb}-\mathrm{Zn}$ mineralization. As is clearly demonstrated by Fig. 14, the radiogenic lead in both the Raahe sandstone boulders and Laisvall-type deposits does not match with juvenile Svecofennian lead and hence their lead and, by inference, zinc were not derived from Svecofennian VMS deposits, even though such Paleoproterozoic mineralization might exist in the bedrock beneath the Bothnian Bay. Such deposits are neither necessary as it has been concluded that even large sandstone-hosted $\mathrm{Pb}-\mathrm{Zn}$ deposits, such as Laisvall or Osen, can be generated by leaching metals from granitoid basement having only tens of ppm of $\mathrm{Pb}$ (Rickard et al., 1981; Bjørlykke \& Thorpe, 1982).

The linear trend and highly radiogenic values of Phanerozoic ore lead compositions illustrated in Fig. 14 can be explained by a two-stage model, with the first growth stage being in a high $\mathrm{U} / \mathrm{Pb}$ environment. Using the regression line based on 88 analyses of galena from Phanerozoic sulfide impregnations in sandstones and galena-bearing veins, Johansson and Rickard (1984) calculated that $\mathrm{Pb}$ was derived from rocks with an age of $1.8 \pm 0.15 \mathrm{Ga}$ and became involved in ore formation at $0.4 \pm 0.15 \mathrm{Ga}$, consistent with the timing of the Svecofennia and Caledonian orogenies, respectively.
Johansson (1983) explained the wide spread in the isotopic ratios in the Phanerozoic ore lead trend by suggesting that the isotopic compositions of the large sandstone-hosted $\mathrm{Pb}-\mathrm{Zn}$ deposits represent an average lead leached in Caledonian times from the local Svecofennian basement, whereas the most radiogenic isotopic compositions in calcite veins are products of selective leaching of $U$ - and Th-rich minerals from the basement and the less radiogenic compositions in quartz veins in turn represent mixtures of radiogenic Svecofennian and less radiogenic Caledonian lead.

Although the $\mathrm{Pb}-\mathrm{Pb}$ isotope method does not provide precise age information for the Raahe boulders, the $\mathrm{Pb}$ isotope data are consistent with the timing of the mineralization process being roughly coeval with the formation of the sandstone-hosted ore deposits or galena-bearing veins at the Caledonian front, though there are still uncertainties in dating of the latter. Saintilan et al. (2015b) obtained a Rb-Sr isochron age of $467 \pm 5$ Ma for sphalerite at Laisvall, but a later attempt by Larsson (2018) did not yield a reasonable age result due to variable initial ratios and/or postdepositional disturbance. Billström et al. (2012) obtained a Rb-Sr isochron age of $534 \pm 13 \mathrm{Ma}$ for sphalerite from the calcite veins in the Storuman area and suggest that these veins were formed before the Caledonian orogeny during a rifting event related to the opening of the Iapetus. Using mineral separates from calcite-fluorite veins sampled at several locations in southern Sweden and Finland, Alm et al. (2005) obtained an average Sm-Nd age of $420 \pm 35 \mathrm{Ma}$ for the veins, being consistent with their connection to the Caledonian orogeny. Instead, the Sm-Nd system applied by Saintilan et al. (2017) to calcite and fluorite from basement veins at Laisvall and Åkerlandet failed to give reasonable geochronological information. The same authors also used the Ar-Ar method to date adularia from the same veins, but only one sample from Åkerlandet gave interpretable results, pointing to an age of around $950-980 \mathrm{Ma}$, which is clearly higher than the Ar-Ar ages (from $528 \pm 10$ to $567 \pm 8 \mathrm{Ma}$ and 
from $453 \pm 8$ to $403 \pm 6 \mathrm{Ma}$ ) measured by Sherlock et al. (2005) for authigenic potassium feldspar in sandstones at Laisvall.

\subsection{Sulfur}

In Fig. 11, a frequency distribution of the $\delta^{34} S$ values in sulfides and sulfates from the Caledonian front $\mathrm{Pb}-\mathrm{Zn}$ occurrences is presented together with isotope data from Raahe boulders. The former include analyses from Laisvall and Vassbo (Rickard et al., 1979, 1981; Saintilan et al., 2016) in central Sweden and Osen, Gjøvik and Galåa in southern Norway (Bjørlykke, 1983). In their overall tendency towards low $\delta^{34} S$ values, iron sulfides in the Raahe boulders differ markedly from sulfides in the impregnation-type $\mathrm{Pb}-\mathrm{Zn}$ mineralization in Paleozoic sediments at Laisvall, Vassbo and other Caledonian occurrences, which contain uniformly heavy sulfur, with galena, sphalerite and pyrite having average $\delta^{34} S$ values of about $+21,+28$, and $+23 \%$, respectively (Fig. 11). An exceptionally low value of $+2.3 \%$ was measured by Saintilan et al. (2015b) for sphalerite from the feeder fault area of the Central Malm at Laisvall. Rare negative values have only been recorded by one pyrite analysis $(-10.1 \%)$ in the upper part of sandstone sequence in contact with overlying shales of the Grammajukku Formation and one framboidal pyrite analysis (-6.4\%o) from the Grammajukku Formation, predating the $\mathrm{Pb}-\mathrm{Zn}$ mineralization event. The mean $\delta^{34} S$ value of barite is around $+20 \%$. Pyrite in the organic-rich shale of the Alum Shale capping the transgressive sedimentary sequence contains relative light sulfur, with $\delta^{34} \mathrm{~S}$ ranging from +14.5 to $+16.0 \%$ at Laisvall (Rickard et al., 1979) and from +6.8 to $+7.6 \%$ at Vassbo (Saintilan et al., 2016). It should be noted that in general, $\delta^{34} S$ in the Alum Shale can vary much more than indicated by these values as shown by a drilling profile made in southern Sweden, giving $\delta^{34} S$ values from -10 to $+20 \%$ (Gill et al., 2011).

The heaviest sulfur isotope compositions of sphalerite $\left(\delta^{34} S\right.$ from +29 to $+33 \%$ ) and galena $\left(\delta^{34} S\right.$ from +22 to $+29 \%$ ) in the Laisvall-type deposits are indistinguishable from the isotopic composition of sulfate in Cambrian to Ordovician seawater (Claypool et al., 1980). They have been explained by relatively high-temperature thermochemical reduction of dissolved seawaterderived sulfate (TSR) by hydrocarbons migrated from the Alum Shale, which was buried and heated under sediments of the early Caledonian foreland basin (Saintilan et al., 2016). Galena and sphalerite with lighter $\delta^{34} S$ values are thought to have a contribution from sulfur produced by thermochemical reductive dissolution of earlier formed barite cement. Barite has $\delta^{34} S$ values down to $+14 \%$, which were interpreted by additional input of relatively light sulfur from the Alum Shale (Saintilan et al., 2016).

The seawater sulfur source coupled with the TSR process can explain the heavy sulfur isotope composition $\left(\delta^{34} S+28.7 \%\right.$ o $)$ measured for one $\mathrm{Pb}$-rich whole-rock sample from Raahe. The other mineral and whole-rock sulfur isotope compositions obtained from the Raahe boulders are outside the typical range of sulfides in the Laisvall-type impregnation ores (Fig. 12), indicating more complicated processes or versatile sources of sulfur. Especially pyrite sulfur shows highly variable compositions, with their $\delta^{34} S$ values going down to $-36 \%$. This kind of light sulfur requires low-temperature microbial sulfate reduction processes for its generation, which in contrast to TSR, can fractionate effectively sulfur isotopes, with the reduced sulfur being tens of \%o units lighter compared to the sulfate precursor (e.g., Goldhaber \& Kapland, 1980). The variability of $\delta^{34} S$ also means mixing of sulfur from different sources, potentially located at least partly in the Precambrian crystalline basement.

The paragenetic sequence established by Saintilan et al. (2016) for the Laisvall ore deposit includes precipitation of minor cementing pyrite together with calcite in a pre- $\mathrm{Pb}-\mathrm{Zn}$ mineralization stage. This was followed by inflow of hydrocarbonbearing fluids, precipitation of barite and partial 
dissolution of carbonate and finally the proper ore-forming stage with precipitation of galena and sphalerite. This scenario can potentially also be applied to the Raahe mineralized sandstone boulders, in which case pyrite and marcasite are the first authigenic sulfides in the rocks. The presence of iron sulfides and also iron hydroxides in the cement prior to the invasion of base metal-bearing fluids would provide iron for subsequent precipitation of chalcopyrite (cf. Ohmoto \& Goldhaber, 1997), constraining the occurrence of chalcopyrite in places where previous iron minerals are available for replacement. The observed heterogeneity of the sulfur isotope compositions indicates a multistage process with different sources of sulfur, with sulfur of iron sulfides being at least partly biogenic in origin as evidenced by their highly negative $\delta^{34} S$ values.

\subsection{Source of dolomitic and basaltic boulders}

Secular variations in $\delta^{13} \mathrm{C}$ of marine carbonates in the rock record has been limited over time with the exception of certain time intervals. The most significant deviations of $\delta^{13} \mathrm{C}$ from the zero value took place in the Jatulian time, which is now seen in heavy carbon isotope compositions measured for dolomitic metasediments in the northern and eastern part of the Fennoscandian Shield (Melezhik et al., 2013). Melezhik and Fallick (2010) reported a large amount of carbon isotope data from the Kalix greenstone belt on the northern shore of the Bothnian Bay. In these data, which are shown in Fig. $12, \delta^{13} \mathrm{C}$ values range from +1 to $+8 \%$ with a maximum at +3 to +4 . There is some variation in $\delta^{13} \mathrm{C}$ in the stratigraphy, with the values becoming slightly more positive upwards in the studied 600-m-thick sedimentary sequence (Wanke \& Melezhik, 2005; Melezhik \& Fallick, 2010). As illustrated by Fig. 12, the $\delta^{13} \mathrm{C}$ values measured for the Raahe dolomite boulders fit well with the Lomagundi-Jatuli anomaly that is observed in the Kalix area and consequently, the Kalix greenstone belt or its submarine extension is a very potential source area for the Raahe dolomite (and quartzite) boulders.

Given the possibility that Ordovician carbonate rocks occur in the Bothnian Bay region, we should compare our carbon isotope results with the carbon isotope signature of Ordovician carbonate rocks. No isotope data are available from such rocks in the Bothnian Bay or Bothnian Sea regions, but some data are available from Ordovician limestones in Estonia. Indeed, a positive carbon isotope excursion has been observed in middle Ordovician (Darriwilian) limestones in Estonia, but $\delta^{34} \mathrm{C}$ values in these rocks remain below $+2.0 \%$ o (Ainsaar et al., 2007). Therefore, we conclude that the dolomitic boulders in the Raahe area represent Jatulian sedimentary rocks derived from the Kalix belt.

The amygdaloidal nature of the mafic volcanic boulders in the Raahe testify that they represent vesicular lavas erupted subareally, being in this sense analogous to the basaltic lavas occurring in the Peräpohja and Kalix belts. Their chemistry suggests negligible interaction with sialic basement and hence they differ from the oldest (Sariolian) Paleoproterozoic volcanics deposited on the Archean basement before the sedimentation of Jatulian quartzites, as these volcanic rocks always display a distinct crustal signature in their trace elements and isotope compositions (e.g., Hanski, 2012). The uncontaminated, MORB-like nature of the basaltic boulders in the Raahe area suggests that they do not originate from Sariolian formations but from a volcanic unit higher in the stratigraphy of the Karelian supracrustal succession, such as the Jouttiaapa Formation in the Peräpohja belt. Many analyzed samples from the Jouttiaapa Formation, particularly those in the lower part of the formation, are clearly more depleted in LREE $\left[(\mathrm{Ce} / \mathrm{Nd})_{\mathrm{CN}}\right.$ $<0.70$ ] and $\mathrm{TiO}_{2}(<0.80$ wt.\%) compared to the Raahe boulders but there exist lava flows with similar $\mathrm{Ce} / \mathrm{Nd}$ and $\mathrm{TiO}_{2}$ (Perttunen \& Hanski, 2003). The Kiiminki belt or its subsea extention can be excluded as a source area for the metavolcanic boulders due to the submarine, non-vesicular nature of its volcanism (Honkamo, 1987). 
Whole-rock XRF data reported by Lager and Loberg (1990) are the only chemical analyses of mafic volcanics currently available to the authors from the Kalix area in Sweden. They show a tholeiitic basalt character as do the Raahe boulders but there are some differences. The compositions reported by Lager and Loberg (1990) seem to be somewhat higher in $\mathrm{TiO}_{2}$ (mostly $1.5-2.8$ wt.\% vs. $1.2-1.4$ wt. $\%)$ and $\mathrm{P}_{2} \mathrm{O}_{5} \quad(0.2-0.3$ wt. $\%$ vs. 0.1 wt. $\%$ ) compared to the Raahe boulders. Precise trace element data have so far not been published from the Kalix belt, but according to the abstract published by Martinsson and Billström (2006), most of the basaltic rocks have a chemical composition resembling that of MORB, with Sm$\mathrm{Nd}$ isotope data giving evidence for their generation from a depleted mantle source. A combination of a continental setting of mafic lava and their MORBtype trace element chemistry is not common in the Precambrian bedrock of the Fennoscandian Shield (Hanski, 2012), but is still characteristic to the Jatulian lavas of the Peräpohja and Kalix belts. Before more rigorous comparison can be made using trace element data, we tentatively suggest that the Raahe metavolcanite boulders together with the dolomitic and quartzitic ones were transported from the Kalix belt or its subsea extension.

\subsection{Source of mineralized sandstone boulders}

No reports are available on findings of similar sandstone erratics on the shore from the western side of the Bothnian Bay in Sweden. Glacial sandstone boulders that were potentially derived from the Laisvall mineralization have been discovered SE of Laisvall, but at maximum, less than $100 \mathrm{~km} \mathrm{SE}$ of the deposit and even these might have originated from elsewhere (L. Bildström, pers. comm., 2017). As mentioned earlier, the $375 \mathrm{~km}$ distance from Laisvall makes it very unlikely that the boulders were transported from the Caledonian front for such a long way, particularly if the concentration of the boulders in a relative small area on the shore near Raahe and their susceptibility to abrasion due to their non-metamorphic nature are taken into account. Sulfur isotopes provide further evidence for the source being elsewhere than in a deposit at the eastern edge of the Caledonides.

Assuming that the associated carbonate boulders were derived from the Kalix belt, lines were drawn from that belt to the shore interval where dolomitic erratics were found during this study. As indicated by Fig. 2, the lines have directions of around $335^{\circ}$ and $342^{\circ}$, passing the Hailuoto Island on its western side. These numbers are consistent with the Late Weichselian transport directions (see Chapter 3.3). Figure 2 also displays the $10 \times 30-\mathrm{km}$-sized area around 20 to $30 \mathrm{~km}$ from the shore that contains sandstone in the Quaternary sea floor sediments and was proposed by Veltheim (1969) to be a potential source area for the mineralized sandstone boulders. The transport direction deduced from Paleoproterozoic carbonate erratics (Fig. 2) seems to not match well with the area indicated by Veltheim (1969), but instead, passes it on its eastern side to the subsea extension of the Hailuoto Formation. So far, one can only speculate on the occurrence of the source area in the zone marked by the two red lines in Fig. 2 .

The studied mineralized sandstone erratics provide indirect evidence for the presence of Cambrian sedimentary rocks at the bottom of the Bothnian Bay, but currently, there is no direct evidence, such as core or dredge samples, demonstrating the existence of Cambrian sedimentary rocks in this area, though suggestions have been made based on geophysics that erosional remnants of such rocks exist in the Bothnian Bay area (Winterhalter et al., 1981; Wannäs, 1989; Winterhalter, 2000). For example, Winterhalter (2000) notes that geophysical data indicate the presence of a depression $5 \mathrm{~km}$ in diameter in the south-central part of the Bothnian Bay, filled with a 500-m-thick sequence of layered sedimentary rocks showing a gravity anomaly. No direct evidence is available for the existence of Ordovician sediments in the Bothnian Bay region, though Uutela (1998) suggests that on the basis of their microfossil contents, the erratic limestone pebbles found at 
Meruanoja, around $60 \mathrm{~km}$ south of Raahe (Eriksson et al., 1999), are Ordovician in age and were derived from the Bothnian Bay area.

The geological observations and ore formation models indicate that the localization of the sandstone-hosted $\mathrm{Pb}-\mathrm{Zn}$ mineralization at Laisvall and other analogous ore occurrences was controlled by an impermeable cap rock unit that terminated the rise of metal-bearing fluids, forcing them to spread laterally along porous sandstone horizons (e.g., Rickard et al., 1979; Saintilan et al., 2016). This was likely the case also in the rock formations that were the source of the Raahe boulders. We might therefore expect to find Grammajukku Formation-type shales or organic-rich shale similar to those of the Alum Shale among the boulders derived from the source area. A more detailed study of the non-deformed mudstone and shale boulders in the shore region is therefore needed.

\subsection{Paleogeographic reconstructions}

After the break-up of Baltica from Laurentia between ca. 570 and $550 \mathrm{Ma}$, Baltica became an independent continent drifted across the southern hemisphere without major tectonic disturbances (Cocks \& Torsvik, 2005). Neoproterozoic weathering had produced a wide, very flat peneplain (Lidmar-Bergström, 1996), the sub-Cambrian basement. Lower Cambrian shelf and shallowmarine epicontinental sediments slowly deposited on this basement, forming a transgressive series starting with conglomerates, which were followed by arenites and quartz arenites. With the sea-level rise and widening of the sedimentary basin, deeperwater shales and muds were accumulated, including the bituminous Alum Shale, which became later covered by Early-Middle Ordovician limestones. Currently, these Lower Paleozoic sediments are mainly outcropping in the Caledonian front and in a zone extending from Estonia via Gotland and Öland to southernmost Sweden, with smaller remnants occurring in southern Sweden, such as the Siljan structure, and the Lauhavuori
Formation (Simonen \& Kouvo, 1955) in central Finland (Fig. 1). Subsea occurrences are represented by the sedimentary deposits at the bottom of the Bothnian Sea and most likely the Bothnian Bay. Due to Phanerozoic tectonic events, the current distribution of Lower Paleozoic strata is patchy, but it is a common view that originally, the Lower Paleozoic sediments formed a more continuous blanket on top of the Precambrian rocks. Evidence for this is provided by clastic sandstone dikes in crystalline basement rocks in southern Sweden (e.g., Friese et al., 2011) and the Aland archipelago (Bergman, 1982) and impact craters filled with remnants of Lower Paleozoic sediments in central and southern Finland (e.g., Lehtovaara, 1992) (Fig. 1).

Paleogeographic reconstructions describing the distribution and evolution of the Lower Paleozoic sedimentary basins on Baltica from the Lower to Middle Cambrian have been published by Nikishin et al. (1996), Cocks and Torsvik (2005) and Nielsen and Schovsbo (2011, 2015). A common feature shared by these models is that for a long time, the Bothnian Bay region was located in the interior of the palaeocontinent hundreds of kilometers away from the continental shelf, without deposition of sedimentary rocks. In the model by Nielsen and Schovsbo $(2011,2015)$, the Bothnian Bay region remained on dry land at the time of deposition of the shelf-type sediments of the Lower and Upper Sandstones at Laisvall (Dominopolian and Ljubomian stages of the Lower Cambrian), subsiding below the sea level not earlier than in the late Lower Cambrian (late VergalianRausvian stage) when the pelitic sediments of the Grammajukku Formation had already accumulated in the Laisvall area. At this stage, the Bothnian Bay formed a northern shallow-marine tongue of the Baltic Sea basin, being separated from the western shelf of Baltica by a NNE-SSW-trending strip of dry land. In the proposed paleobasin reconstruction, this situation with no direct connection of the depositional sites between the Laisvall area and the Bothnian Bay continued until the Middle Cambrian when marine transgression caused 
expansion of the epicontinental sea and deposition of the Alum Shale over a wide area in western Scandinavia.

\subsection{Ore formation and reactivation of the Precambrian basement}

In analogy with the origin of Mississippi Valley type ore deposits (e.g., Leach et al., 2010), most authors are of the opinion that the formation of sandstone-hosted $\mathrm{Pb}-\mathrm{Zn}$ deposits in the Caledonian front is epigenetic and related to the Caledonian collisional orogeny (e.g., Duane \& de Wit, 1988; Saintilan et al., 2015b) though arguments have also been presented for a syngenetic origin (Bjørlykke \& Thorpe, 1982; Bjørlykke et al., 2019). Before Cenozoic opening of the North Atlantic, the Caledonian orogen between Scandinavia and Greenland had dimensions comparable to those of the Himalaya, having a width of approximately $700-800 \mathrm{~km}$ and allochthons with several hundreds of kilometers of lateral emplacement (Gee et al., 2008, 2010). It is likely that on the eastern side of the orogen, the thrust sheets extended eastwards over the foreland platform for a much longer distance than what they do today (Gee et al., 2008).

The conceptual models used to explain the generation of carbonate-hosted MVT $\mathrm{Pb}-\mathrm{Zn}$ ore deposits as well as sandstone-hosted $\mathrm{Pb}-\mathrm{Zn}$ deposits involve collisional orogeny-driven regional fluid flow progressing towards the foreland basin, with the hydrodynamic system occurring over a distance of several hundreds of kilometers (e.g., Garven et al., 1993). In the ore formation models of the Laisvall-type $\mathrm{Pb}-\mathrm{Zn}$ deposits suggested by many authors (e.g., Romer, 1992; Kendrich et al., 2005; Saintilan et al., 2015a, 2016), the localization of the mineralization is controlled by reactivation of earlier large-scale tectonic structures in the Proterozoic basement during the Caledonian orogeny, allowing fluid movement and metal leaching in the fractured bedrock. The most important of them are orogenytransverse faults in the basement close to the Caledonian front, which in the Laisvall area, for example, strike NNW-SSE (Romer, 1992; Saintilan et al., 2015b), or other inhomogeneities in the basement, such as mafic dikes in the Vassbo area (Christofferson et al., 1979). The location of the assumed source of the Raahe sandstone boulders is optimal in this sence as this area is situated near the collisional megastructure between the Archean craton margin and Svecofennian arc complex (Fig. 1). Moreover, starting from the middle Riphean, the Gulf of Bothnia has been subjected block faulting events, which produced a depression where Jotnian to Paleozoic sedimentary formations were preserved (Lidmar-Bergström, 1996; Winterhalter, 2000).

It is reasonable to assume that if the ore-forming processes generating the Laisvall-type deposits in the Caledonian front and those leading to the metal enrichment in the source of the Raahe boulders were linked to the same mineralization event, both of these areas belonged to the same depositional basin during the ore formation. However, the paleogeographical reconstructions discussed above do not allow such a joint basinal brine flow system between these two areas. Moreover, in the case of the Laisvall-type deposits, reactivation of basement structures and mixing of ore-forming fluids are thought have taken place in a forebulge setting with flexure-induced normal faulting in the basement (Saintilan et al., 2015a, 2016). The assumed source area of the Raahe boulders is situated in the Gulf of Bothnian, a basin which was a locus of rifting for several times since the Mesoproterozoic (LidmarBergström, 1996). This leads to a question of how forebulge migration would interact with the paleorift represented by the Gulf of Bothnia.

Reactivation of the Precambrian basement and related fluid flow can be studied using minerals precipitated as fracture fillings in the bedrock (e.g., Tullborg et al., 2008). It is well documented that hydrothermal calcite-fluorite veins with variable amounts of other minerals (quartz, galena, pyrite, marcasite, sphalerite and chalcopyrite) occur in the crystalline basement, having been formed in response to far-field effects from several orogenies (e.g., Drake et al., 2009). In this connection, we are interested in the veins that can be potentially 
connected to the Caledonian orogeny. As was discussed earlier, there are galena-bearing veins with radiogenic ore lead in the basement that are spatially closely associated with base metal dissemination in the overlying Paleozoic sandstones (Johansson, 1983; Saintilan et al., 2015a). However, this kind of veins are not restricted in the Caledonian front but are scattered widely in the shield area, including occurrences in southern Sweden, Aland Island, SW and SE Finland, western coast of the Gulf of Bothnia, Barents Sea coast (Peuravuono), and NE corner of the White Sea (marked as red crosses in Fig. 1), as summarized by Alm and Sundblad (2002) and Alm et al. (2005). Using fluorite and calcite analyses from several locations, Alm et al. (2005) obtained an average $\mathrm{Sm}-\mathrm{Nd}$ age of $420 \pm 35 \mathrm{Ma}$ for the veins, being consistent with their connection to the Caledonian orogeny.

Another way to assess the lead mobility is to analyze $\mathrm{Pb}$ isotope compositions of galena in base metal deposits in the Precambrian bedrock. R. Romer and his colleagues have produced a lot of $\mathrm{Pb}-\mathrm{Pb}$ isotope data from several Paleoproterozoic base metal occurrences in northern Sweden (blue crosses in Fig. 1), which contain galena with variably radiogenic isotope compositions plotting on a trend similar to the Caledonian radiogenic ore trend (Romer \& Boundy, 1988; Romer, 1989a,b; Romer \& Leino, 1989; Romer \& Wright, 1993). This has been taken as evidence for migration of lead from the crystalline basement during the Caledonian orogeny, with the Paleoproterozoic base metal enrichments acting as traps for radiogenic lead mobilized from the basement. Romer and Wright (1993) suggest that this phenomenon has taken place within a zone extending at least for $100 \mathrm{~km}$ towards the foreland from the presentday Caledonian erosional front. We can add that Mänttäri (1995) discovered radiogenic lead in some Paleoproterozoic base metal and gold deposits in the Kittilä area in Finnish Lapland (Fig. 1), with ${ }^{206} \mathrm{~Pb} /{ }^{204} \mathrm{~Pb}$ in galena reaching values up to 24.4 , thus expanding the width of the $\mathrm{Pb}$ remobilization zone to around $200 \mathrm{~km}$. The Raahe boulders provide further evidence for basement reactivation far from the current Caledonian front, but geochronological data on the timing of metal precipitation in the Raahe boulders are needed to confirm its relationship to the Caledonian orogeny.

\section{Conclusions}

Several conclusions can be drawn from this study, including:

1. Mineralized quartz sandstone boulders found at the coast near Raahe represent mature nonmetamorphic shelf sediments whose $\mathrm{Zn}-\mathrm{Pb}-\mathrm{Cu}$ enrichment is epigenetic in origin and was formed when the sediments were not yet completely consolidated.

2. Lead isotope evidence suggests that the mineralization event was coeval with the Laisvall-type sandstone-hosted $\mathrm{Pb}-\mathrm{Zn}$ deposits at the Caledonian front, whose genesis is related to the Caledonian orogeny, and the source of base metals were in the Paleoproterozoic Svecofennian granitoid basement.

3. Sulfur isotope compositions of sulfides in the Raahe boulders are heterogeneous and often show negative $\delta^{34} S$ values, indicating that sulfur is partially biogenic in origin. This feature makes the boulders different from the sandstones hosting the Laisvall and Vassbo deposits with heavy sulfur and can be used together with a long distance from the Caledonian front as evidence for another, closer source of the boulders, most likely at the bottom of the Bothnian Bay. More in-situ $S$ isotope data from different sulfide minerals are needed to test their paragenetic relationship.

4. Carbonate rock boulders show a positive carbon isotope anomaly and amygdaloidal metabasalt boulders have a MORB-like trace element signature, which indicate that these boulders together with quartzite boulders are derived from the Kalix belt in Sweden, providing a probable transportation direction for the mineralized sandstone erratics as well. 
5. Assuming the source of the Raahe sandstone boulders at the bottom of the Bothnian Bay, we can conclude that in central Scandinavia, mobilization of base metals in the Precambrian basement due to the Caledonian orogeny extends at least $300 \mathrm{~km}$ to the $\mathrm{SE}$ from the present-day Caledonian front.

6. The occurrence of Cambrian clastic sediments in the Gulf of Bothnian is likely not restricted in the Bothnian Sea region but extends to the Bothnian Bay. Whether the Hailuoto Formation belongs to these sediments is one of the challenges to future research.

\section{References}

Ainsaar, L., Meidla, T., Tinn, O., Martma, T., Dronov, A. 2007. Darriwilian (middle Ordovician) carbon isotope stratigraphy in Baltoscandia. Acta Palaeontologica Sinica 46 (Suppl.), 1-8.

Alm, E. \& Sundblad, K., 2002. Fluorite-calcite-bearing fractures in the counties of Kalmar and Blekinge, Sweden. SKB R-02-42, Svensk Kärnbränslehantering AB, 116 p.

Alm, E., Sundblad, K. \& Huhma, H., 2005. Sm-Nd isotope determinations of low-temperature fluoritecalcite-galena mineralization in the margins of the Fennoscandian Shield. SKB R-05-66, Svensk Kärnbränslehantering $\mathrm{AB}, 58 \mathrm{p}$.

Ayrault, S., 2008. Geology and mineral resources of the Lövstrand $\mathrm{Pb}(-\mathrm{Zn})$ mineralization Dorotea area, northcentral Sweden. MSc Thesis, Luleå University of Technology, Sweden, 63 p.

Bergman, L., 1982. Clastic dykes in the Alland islands, SW Finland and their origin. Geological Survey of Finland, Bulletin 317, 7-33.

Bergman, L. \& Lindberg, B., 1979. Phanerozoic veins of galena in the Åland rapakivi area, southwestern Finland. Bulletin of the Geological Society of Finland 51, 55-62. https://doi.org/10.17741/bgsf/51.1-2.006

Billström, K. \& Weihed, P., 1996. Age and provenance of host rocks and ores in the Paleoproterozoic Skellefte district, northern Sweden. Economic Geology 91, 1054-1072. https://doi.org/10.2113/gsecongeo.91.6.1054

Billström, K. \& Vivallo, W., 1994. Synvolcanic mixing of ore lead and the development of lead isotopic provinces in the Skellefte district, Sweden. Mineralium Deposita 29, 111119. https://doi.org/10.1007/BF00191508

Billström, K., Broman, C., Schneider, J., Pratt, W. \& Skogsmo, G., 2012. Zn-Pb ores of Mississippi Valley Type in the Lycksele-Storuman district, northern Sweden: A possible

\section{Acknowledgements}

We are grateful to Pyhäsalmi Mine Oy for providing us with boulder samples from the Raahe area. We thank Kjell Billström and Kalle Kirsimae for their constructive criticism on the manuscript. The first author acknowledges support from the Academy of Finland (grant\#281859).

rift-related Cambrian mineralisation event. Minerals 1, 169-207. https://doi.org/10.3390/min2030169

Bjørlykke, A., 1983. Sulphur isotope composition of the sandstone-lead deposits in southern Norway. Norges Geologiske Undersøkelse, Bulletin 380, 143-158.

Bjørlykke, A. \& Sangster, D.F., 1981. An overview of sandstone lead deposits and their relation to red-bed copper and carbonate-hosted lead-zinc deposits. Economic Geology, $75^{\text {th }}$ Anniversary Volume, 179-213. https://doi.org/10.5382/AV75.07

Bjørlykke, A. \& Thorpe, R.I., 1982. The source of lead in the Osen sandstone lead deposit on the Baltic Shield. Economic Geology 77, 430-440. https://doi.org/10.2113/gsecongeo.77.2.430

Bjørlykke, A., Cumming, G.L. \& Krstic, D., 1990. New isotopic data from davidites and sulfides in the Bidjovagge gold-copper deposit, Finnmark, northern Norway. Mineralogy and Petrology 43, 1-21. https://doi.org/10.1007/BF01164218

Bjørlykke, A., Bingen, B., Billström, K. \& Kooijman, E., 2019. The sandstone-hosted Osen lead deposit, Norway: new $\mathrm{Pb}$ isotope evidence for sourcing in the underlying granitoid basement. Norwegian Journal of Geology 99, in press. https://dx.doi.org/10.17850/njg98-4-04

Casanova, V., 2010. Geological and geophysical characteristics of the $\mathrm{Pb}-\mathrm{Zn}$ sandstone-hosted autochthonous Laivall deposit in the perspective of regional exploration at the Swedish Caledonian Front. MSc Thesis, Luleå University of Technology, Sweden, $32 \mathrm{p}$.

Christofferson, H.C., Wallin, B., Selkman, S. \& Rickard, D.T., 1979. Mineralization controls in the sandstone leadzinc deposits at Vassbo, Sweden. Economic Geology 74, 1239-1249.

https://doi.org/10.2113/gsecongeo.74.5.1239 
Claypool, G.E., Holser, W.T., Kaplan, I.R., Sakai, H. \& Zak, I., 1980. The age curves of sulfur and oxygen isotopes in marine sulfate and their mutual interpretation. Chemical Geology 28, 199-260. https://doi.org/10.1016/0009-2541(80)90047-9

Cocks, L.R.M. \& Torsvik, T.H., 2005. Baltica from the late Precambrian to mid-Palaeozoic times: The gain and loss of a terrane's identity. Earth-Science Reviews 72, 39-66. https://doi.org/10.1016/j.earscirev.2005.04.001

Cuzzone, J.K., Clark, PU., Carlson, A.E., Ullman, D.J., Rinterknecht, V.R., Milne, G.A., Lunkka, J.P., Wohlfarth, B., Marcott, S.A. \& Caffee, M. 2016. Final deglaciation of the Scandinavian Ice sheet and implications for the Holocene global sea-level budget. Earth and Planetary Science Letters 448, 34-41. https://doi.org/10.1016/j.epsl.2016.05.019

DigiKP, 2018. Bedrock of Finland 1:200 000 - Digital map database [dataset]. Espoo, Geological Survey of Finland (accessed 21 August 2018), https://hakku.gtk.fi/en/locations/search

Donner, J. 1995. The Quaternary history of Scandinavia. World and Regional Geology 7, Cambridge University Press, Cambridge, UK, 199 p.

Drake, H., Tullborg, E.-L. \& Page, L., 2009. Distinguished multiple events of fracture mineralisation related to farfield orogenic effects in Paleoproterozoic crystalline rocks, Simpevarp area, SE Sweden. Lithos 110, 37-49. https://doi.org/10.1016/j.lithos.2008.12.003

Duane, M.J. \& de Wit, M.J., 1988. Pb-Zn ore deposits of the northern Caledonides: Products of continentalscale fluid mixing and tectonic expulsion during continental collision. Geology 16, 999-1002. https://doi. org/10.1130/0091-7613(1988)016<0999:PZODOT>2 .3. $\mathrm{CO} ; 2$

Eriksson, B., Grönlund, T. \& Uutela, A., 1999. Biostratigraphy of the Eemian and Weichselian sediments at Mertuanoja, Ostrobothnia, western Finland. Boreas 28, 274-291. https://doi.org/10.1111/j.1502-3885.1999.tb00220.x

Fontboté, L. \& Saintilan, N., 2018. Reply to discussion of "A refined genetic model for the Laisvall and Vassbo Mississippi Valley-type sandstone-hosted deposits, Sweden: constraints from paragenetic studies, organic geochemistry, and S, C, N, and Sr isotope data" by D. Sangster. Mineralium Deposita 53, 295-297. http://link.springer.com/10.1007/s00126-017-0785-x

Friese, N., Vollbrecht, A., Leiss, B. \& Jacke, O. 2011. Cambrian sedimentary dykes in the Proterozoic basement of the Västervik area (southeast Sweden): episodic formation inferred from macro- and microfabrics. International Journal of Earth Science 100, 741-752. https://doi.org/10.1007/s00531-009-0508-3

Garven, G., Ge, S., Person, M.A. \& Sverjensky, D.A., 1993. Genesis of stratabound ore deposits in the midcontinent basins of North America. 1. The role of regional groundwater flow. American Journal of Science, 293, 497-568. doi:10.2475/ajs.293.6.497
Gee, D.G., Fossen, H., Henriksen, N. \& Higgins, A.K., 2008. From the early Paleozoic platforms of Baltica and Laurentia to the Caledonide Orogen of Scandinavia and Greenland. Episodes 31, 44-51.

Gee, D.G., Juhlin, C., Pascal, C. \& Robinson, P., 2010. Collisional orogeny in the Scandinavian Caledonides (COSC). GFF 132, 29-44. https://doi.org/10.1080/11035891003759188

Gilbert, S.E., Danyushevsky, L.V., Rodermann, T., Shimizu, A., Gurenko, A., Meffre, S., Thomas, H., Large, R.R. \& Death, D., 2014. Optimisation of laser parameters for the analysis of sulphur isotopes in sulphide minerals by laser ablation ICP-MS. Journal of Analytical Atomic Spectrometry 29, 1042-1051. DOI: 10.1039/C4JA00011K

Gill, B.C., Lyons, T.W., Seth A. Young, A.A., Kump, L.R., Knoll, A.H. \& Saltzman, M.R., 2011. Geochemical evidence for widespread euxinia in the Later Cambrian ocean. Nature 469, 80-83.

Goldhaber, M. \& Kapland, I.R., 1980. Mechanisms of sulfur incorporation and isotope fractionation during early diagenesis in sediments of the Gulf of California. Marine Chemistry 9, 95-143. https://doi.org/10.1016/0304-4203(80)90063-8

Grip, E., 1960. The lead deposits of the eastern border of the Caledonides in Sweden. XXII International Geological Congress, Norden, Pt XVI, p. 149-159.

Hallberg, A., 1989. Metal sources in the Early Proterozoic Svecofennian terrain of central Sweden: $\mathrm{Pb}$ isotope evidence. Mineralium Deposita 24, 250-257. https://doi.org/10.1007/BF00206387

Hanski, E., 2012. Evolution of the Palaeoproterozoic (2.50$1.95 \mathrm{Ga}$ ) non-orogenic magmatism in the eastern part of the Fennoscandian Shield. In: Melezhik, V.A., Prave, A.R., Hanski, E.J., Fallick, A.E., Lepland, A., Kump, L.R., Strauss, H. (eds.), Reading the Archive of Earth's Oxygenation. Volume 1: The Palaeoproterozoic of Fennoscandia as Context for the Fennoscandian Arctic Russia - Drilling Early Earth Project, Springer-Verlag, Berlin, Heidelberg, pp. 179-245.

Hellaakoski, A., 1940. On the movement directions of the glacier in the Ostrobothnian coastal area and the environment of Tampere. Fennia 67, 1-30. (in Finnish)

Hellström, F.A., Kumpulainen, R., Jönsson, C., Thomsen, T.B., Huhma, H. \& Martinsson, O., 2018. Age and lithostratigraphy of Svecofennian volcano sedimentary rocks at Masugnsbyn, northernmost Sweden - host rocks to $\mathrm{Zn}-\mathrm{Pb}-\mathrm{Cu}-$ and $\mathrm{Cu} \pm \mathrm{Au}$ sulphide mineralisations. In: Bergman, S. (ed.), Geology of the Northern Norrbotten Ore Province, Northern Sweden. Sveriges Geologiska Undersökning, Rapporter och Meddelanden 141, 151203.

Honkamo, M. 1987. Geochemistry and tectonic setting of Early Proterozoic volcanic rocks in Northern Ostrobothnia, Finland. In: Pharaoh, T.C., Beckinsale, R.D. \& Rickard, D. (eds.) Geochemistry and Mineralisation of Proterozoic Suites. Geological Society Special Publication 33, 59-68. 
Huhta, P., 1985. Studies of Quaternary deposits supporting exploration in the Raahe area, map sheets 244104,05 , 07 and 08. Geological Survey of Finland, Unpublished Report P13.2.069, 2 p. (in Finnish)

Hytönen, K., 1968. A preliminary report on an iron-rich formation near Raahe in the Gulf of Bothnia, Finland. Bulletin of the Geological Society of Finland 40, 135-144.

Hyyppä, E., 1948. Tracing the source of the pyrite stones from Vihanti on the basis of glacial geology. Bulletin de la Commission géologique de Finlande 142, 97-122.

Ignatius, H., Kukkonen, E. \& Winterhalter, B., 1980. The Quaternary deposits of the Gulf of Bothnia. Geological Survey of Finland, Report of Investigation 45, 50 p. (in Finnish with English summary)

Iisalo, E., 1992. Observations on the stratigraphy of Weichselian tills and subtill eskers in central Ostrobothnia, Finland. Geological Survey of Finland, Report of Investigation $112,42 \mathrm{p}$.

Iisalo, E., 2003. Till stratigraphy and geochemical diffrences between till beds in western Finland. In: Räisänen, M., Nikkarinen, M. (eds.), Complexity of Glacial Dispersal and Hydromorphic Processes in Till Geochemistry. Geological Survey of Finland, Special Paper 34, 21-42.

Johansson, A. 1983. Lead isotope composition of Caledonian sulphide-bearing veins in Sweden. Economic Geology 78, 1674-1688. https://doi.org/10.2113/gsecongeo.78.8.1674

Johansson, Å. \& Rickard, D.T., 1984. Isotopic composition of Phanerozoic ore leads from the Swedish segment of the Fennoscandian Shield. Mineralium Deposita 19, 249 255. https://doi.org/10.1007/BF00204377

Johansson, Å. \& Rickard, D.T., 1985. Some new lead isotope determinations from the Proterozoic sulfide ores of Central Sweden. Mineralium Deposita 20, 1-7.

https://doi.org/10.1007/BF00204252

Johansson, P., Lunkka, J. P. \& Sarala, P. 2011. Glaciation of Finland. In: Ehlers, J., Gibbard, P.L., Hughes, P.D. (eds.), Developments in Quaternary Science, Vol.15, Elsevier, Amsterdam, pp. 105-116.

Kähkönen, Y., 2005. Svecofennian supracrustal rocks. In: Lehtinen, M., Nurmi, P.A., Rämö, O.T. (eds.), Precambrian Geology of Finland - Key to the Evolution of the Fennoscandian Shield. Elsevier B.V., Amsterdam, pp. 343-406. https://doi.org/10.1016/S0166-2635(05)80009-X

Karhu, J.A., 2005. Paleoproterozoic carbon isotope excursion. In: Lehtinen, M., Nurmi, P.A., Rämö, O.T. (eds.), Precambrian Geology of Finland - Key to the Evolution of the Fennoscandian Shield. Elsevier, Amsterdam, pp. 669-680. https://doi.org/10.1016/S0166-2635(05)80017-9

Kendrick, M.A., Burgess, R., Harrison, D. \& Bjørlykke, A., 2005. Noble gas and halogen evidence for the origin of Scandinavian sandstone-hosted $\mathrm{Pb}-\mathrm{Zn}$ deposits. Geochimica et Cosmochimica Acta 69, 109-129. doi.org/10.1016/j.gca.2004.05.045
Kohonen, J. \& Rämö, O.T., 2005. Sedimentary rocks, diabases, and late cratonic evolution. In: Lehtinen, M., Nurmi, P.A., Rämö, O.T. (eds.), Precambrian Geology of Finland - Key to the Evolution of the Fennoscandian Shield. Elsevier B.V., Amsterdam, pp. 563-604. https://doi.org/10.1016/S0166-2635(05)80014-3

Kousa, J. \& Lundqvist, T., 2000. Svecofennian Domain. In: Lundqvist, T., Autio, S. (eds.) Description to the Bedrock Map of Central Fennoscandia (Mid-Norden). Geological Survey of Finland, Special Paper 28, 47-75.

Lager, I., \& Loberg, B., 1990. Sedimentological and basin analysis ore prospecting methods in the North Bothian greenstone belt. STU-Project 86-03967P, Final Report, Luleå Technical University, Sweden, 112 p. (in Swedish)

Lahtinen, R., Korja, A. \& Nironen, M. 2005. Palaeoproterozoic tectonic evolution of the Fennoscandian Shield. In: Lehtinen, M., Nurmi, P. A. \& Rämö, O. T. (eds), Precambrian Geology of Finland - Key to the Evolution of the Fennoscandian Shield. Elsevier, Amsterdam, pp. 418-532.

Lahtinen, R., Huhma, H., Lahaye, Y., Lode, S., Heinonen, S., Sayab, M. \& Whitehouse, M.J., 2016. Paleoproterozoic magmatism across the Archean-Proterozoic boundary in central Fennoscandia: Geochronology, geochemistry and isotopic data ( $\mathrm{Sm}-\mathrm{Nd}$, Lu-Hf, O). Lithos 262, 507-525. https://doi.org/10.1016/j.lithos.2016.07.014

Larsson, A., 2018. Rb-Sr sphalerite data and implications for the source and timing of $\mathrm{Pb}-\mathrm{Zn}$ deposits at the Caledonian margin in Sweden. M,Sc. Thesis, University of Lund, Sweden, $34 \mathrm{p}$.

Leach, D.L., Bradley, D.C., Huston, D., Pisarevsky, S.A., Taylor, R.D. \& Gardoll, S.J., 2010. Sediment-hosted lead-zinc deposits in Earth history. Economic Geology 105, 593-625.

https://doi.org/10.2113/gsecongeo.105.3.593

Lehtovaara, J.J., 1992. Söderfärden: a Cambrian impact crater in western Finland. Tectonophysics 216, 157-161. https://doi.org/10.1016/0040-1951(92)90162-Y

Lidmar-Bergström, K., 1996. Long term morphotectonic evolution in Sweden. Geomorphology 16, 33-59. https://doi.org/10.1016/0169-555X(95)00083-H

Lundqvist, T., Autio, S. (eds.), 2000. Description to the Bedrock Map of Central Fennoscandia (Mid-Norden). Geological Survey of Finland, Special Paper 28, 176 p.

Lunkka, J.P., Johansson, P., Saarnisto, M. \& Sallasmaa, O. 2004. Glaciation of Finland. In: Ehlers, J., Gibbard, P.L. (eds.), Quaternary Glaciations - Extent and Chronolog, Part I: Europe. Elsevier, Amsterdam, pp. 93-100.

Lunkka, J.P., Lintinen, P., Nenonen, K. \& Huhta, P. 2016. Stratigraphy of the Koivusaarenneva exposure, and its correlation across central Ostrobothnia, Finland. Bulletin of the Geological Society of Finland 88, 53-67. DOI 10.17741/bgsf/88.2.001

Luukas, J., Kousa, J., Nironen, M \& Vuollo, J. 2017. Major stratigraphic units in the bedrock of Finland, and an approach to tectonostratigraphic division. Geological Survey of Finland, Special Paper 60, 9-40. 
Mäki, T., Kousa, J. \& Luukas, J., 2015. The Vihanti-Pyhäsalmi belt. In: Maier, W., O’Brien, H., Lahtinen, R. (eds.), Mineral Deposits of Finland. Elsevier, Amsterdam, pp. 507-530.

https://doi.org/10.1016/B978-0-12-410438-9.00020-0

Makkonen, V., 1971. Investigations in the coastal area in summer 1970. Rautaruukki Oy Exploration, Unpublished Report Ou No. 3/71,7 p. (in Finnish)

Makkonen, H.V., 2015. Nickel deposits of the $1.88 \mathrm{Ga}$ Kotalahti and Vammal belts. In: Maier, W., O’Brien, H., Lahtinen, R. (eds.), Mineral Deposits of Finland. Elsevier, Amsterdam, pp. 253-303. https://doi.org/10.1016/B978-0-12-410438-9.00010-8

Mänttäri, I., 1995. Lead isotope characteristics of epigenetic gold mineralization in the Palaeoproterozoic Lapland greenstone belt, northern Finland. Geological Survey of Finland, Bulletin 381,70 p.

Martinsson, O. \& Billström, K., 2006. Plume related MORB and high-Ti basalts in the Kalix greenstones, northern Sweden. Bulletin of the Geological Society of Finland, Special Issue 1, 2006, p. 98.

Melezhik, V.A, \& Fallick, A.E., 2010. On the LomagundiJatuli carbon isotopic event: The evidence from the Kalix Greenstone Belt, Sweden. Precambrian Research 179, 165-190. https://doi.org/10.1016/j.precamres.2010.03.002

Melezhik, V.A., Fallick, A.E., Brasier, A.T. \& Salminen, P., 2013. Lomagundi-Jatuli excursion as seen from the Fennoscandian Shield record. In: Melezhik, V.A., Fallick, A.E., Strauss, H., Hanski, E.J., Prave, A.R., Lepland, A. (eds.), Reading the Archive of Earth's Oxygenation. Volume 3: Global Events and the Fennoscandian Arctic Russia - Drilling Early Earth Project, Springer-Verlag, Berlin, Heidelberg, pp. 1117-1123.

Molnár, F., Mänttäri, I., O’Brien, H., Lahaye, Y., Pakkanen, L., Johanson, B., Käpyaho, A., Sorjonen-Ward, P., Whitehouse, M. \& Sakellaris, G., 2016a. Boron, sulphur and copper isotope systematics in the orogenic gold deposits of the Archaean Hattu schist belt, eastern Fnland. Ore Geology Reviews 77, 133-162. https://doi.org/10.1016/j.oregeorev.2016.02.012

Molnár, F., O’Brien, H., Lahaye, Y., Käpyaho, A., SorjonenWard, P., Hyodo, H. \& Sakellaris, G., 2016b. Signatures of multiple mineralization processes in the Archean orogenic gold deposit of the Pampalo Mine, Hattu schist belt, eastern Finland. Economic Geology 111, 16591703. https://doi.org/10.2113/econgeo.111.7.1659

Müller, W., M. Shelley, Miller, P. \& Broude, S., 2009. Initial performance metrics of a new custom-designed $\mathrm{ArF}$ excimer LA-ICPMS system coupled to a two-volume laser-ablation cell. Journal of Analytical Atomic Spectrometry 24, 209-214. 10.1039/B805995K

Nenonen, K. 1995. Pleistocene Stratigraphy and Reference Sections in Southern and Western Finland. Geological Survey of Finland, Kuopio, 205 p.
Nenonen, K., Eriksson, T. \& Grönlund, T. 1991. The till stratigraphy of Ostrobothnia, western Finland with reference to new Eemian interglacial sites. Striae 34, 6576.

Nielsen, A.T. \& Schovsbo, N.H., 2011. The Lower Cambrian of Scandinavia: Depositional environment, sequence stratigraphy and palaeogeography. Earth-Science Reviews 107, 207-310. https://doi.org/10.1016/j.earscirev.2010.12.004

Nielsen, A.T. \& Schovsbo, N.H., 2015. The regressive EarlyMid Cambrian 'Hawke Bay Event' in Baltoscandia: Epeirogenic uplift in concert with eustasy. Earth-Science Reviews 151, 288-350. https://doi.org/10.1016/j.earscirev.2015.09.012

Niemelä, J., Ekman, I. \& Lukashov, A. (eds.), 1993. Quaternary Deposits of Finland and Northwestern Part of Russian Federation and their Resourches. Map Scale 1:1000 000. Geological Survey of Finland and Institute of Geology, Karelian Research Centre, Russian Academy of Sciences.

Niemelä, M., 1983. Investigations of zinc-, lead- and copperbearing sandstone boulders in the Raahe area in years 1981-1982. Geological Survey of Finland, Unpublished Report M19/2441/-83/1/10, 21 p. (in Finnish)

Nikander, J., 2000. Ore geological investigations in the areas of the Raahe and Pattijoki municipalities on map sheet 2441 08 in years 1994-1996. Geological Survey of Finland, Unpublished Report M19/2441/2000/2/10, 15 p. (in Finnish)

Nikishin, A.M., Ziegler, P.A., Stephenson, R.A., Cloetingh, S.A.P.L., Furne, A.V., Fokin, P.A., Ershov, A.V., Bolotov, S.N., Korotaev, M.V., Alekseev, A.S., Gorbachev, V.I., Shipilov, E.V., Lankreijer, A., Bembinova, E.Y. \& Shalimov, I.V., 1996. Late Precambrian to Triassic history of the East European Craton: dynamics of sedimentary basin evolution. Tectonophysics 268, 23-63. https://doi.org/10.1016/S0040-1951(96)00228-4

Nykänen, O., 1959. Raahe-Paavola. Explanation to the Geological map of Finland, 1:100 000, pre-Quaternary rocks map sheets 2441-2443, Geological Survey of Finland, Espoo, 38 p. (In Finnish with English summary) http://tupa.gtk.fi/kartta/kallioperakartta100/ kps_2441_2443.pd

Ohmoto, H. \& Goldhaber, M.B., 1997. Sulfur and carbon isotopes. In: Barnes, H.L. (ed.), Geochemistry of Hydrothermal Ore Deposits, Wiley, New York, pp. 517611.

Okko, V., 1949. Kokkola. Explanation to the General Geological Map of Finland 1:400 000, Quaternary deposits, sheet B4,. Geological Survey of Finland, Espoo, 55 p. (in Finnish with English summary)

Perttunen, V., 1985. On the Proterozoic stratigraphy and exogenic evolution of the Peräpohja area, Finland. Bulletin of the Geological Society of Finland 380, 131141. 
Perttunen, V. \& Hanski, E., 2003. Koivu-Törmäsjärvi. Explanation to the Geological map of Finland 1:100 000, pre-Quaternary rocks, sheets 3631 and 2633. Geological Survey of Finland, Espoo, 88 p. (in Finnish with English summary).

Rickard, D.T. \& Svensson, S-Å., 1984. Ore lead isotope variations in the Proterozoic massive pyrite deposit at Näsliden, Skellefte district, Sweden. Mineralium Deposita 19, 145-151. https://doi.org/10.1007/BF00204677

Rickard, D.T., Willdén, M.Y., Marinder, N.-E. \& Donnelly, T.H., 1979. Studies on the genesis of the Laisvail sandstone lead-zinc deposit, Sweden. Economic Geology $74,1255-1285$. https://doi.org/10.2113/gsecongeo.74.5.1255

Rickard, D., Coleman, M. \& Swainbank, I., 1981. Lead and sulfur isotopic compositions of galena from the Laisvall sandstone lead-zinc deposit, Sweden. Economic Geology 76, 2042-2046. https://doi.org/10.2113/gsecongeo.76.7.2042

Robb, L.J., 2005. Introduction to Ore-Forming Processes. Blackwell Science Ltd, Malden, 373 p

Romer, R.L., 1989a. Interpretation of the lead isotope composition from sulfide mineralizations in the Proterozoic Sjangeli area, northern Sweden. Geological Survey of Norway, Bulletin 415, 57-69.

Romer, R.L., 1989b. Trace lead composition of sulfides from mineralizations in the Proterozoic Råppe supracrustal belt, northern Sweden. GFF 111, 155-160. https://doi.org/10.1080/11035898909453789

Romer, R.L., 1990. Lead mobilization during foreland metamorphism in orogenic belts: Examples from northern Sweden. Geologische Rundschau 79, 693-707. DOI: $10.1007 / \mathrm{BF} 01879209$

Romer, R.L., 1992. Sandstone-hosted lead-zinc mineral deposits and their relation to the tectonic mobilization of the Baltic shield during the Caledonian orogeny $-\mathrm{A}$ reinterpretation. Mineralogy and Petrology 47, 67-85. https://doi.org/10.1007/BF01165298

Romer, R., 1993. Metallogeny and lead isotope composition of base metal sulfide deposits in the Rappen area, northern Sweden. Mineralium Deposita 28, 37-46. https://doi.org/10.1007/BF00199008

Romer, R., 1994. Caledonian upgrading of Proterozoic low-grade base-metal deposits in Northern Sweden. Mineralogy and Petrology 50, 271-285. https://doi.org/10.1007/BF01164610

Romer, R. \& Boundy, T.M., 1988. Interpretation of lead isotope data from the uraniferous $\mathrm{Cu}-\mathrm{Fe}$-sulfide mineralizations in the Proterozoic greenstone at Kopparåsen, northern Sweden. Mineralium Deposita 23, 256-261. https://doi.org/10.1007/BF00206404

Romer, R.L. \& Leino, H., 1989. Pb-Sr-Nd isotope data from the Valasjaure supracrustal belt, northern Sweden. GFF $111,155-160$.

https://doi.org/10.1080/11035898909452706
Romer, R.L. \& Wright, J.E., 1993. Lead mobilization during tectonic reactivation of the western Baltic Shield. Geochimica et Cosmochimica Acta 57, 2555-2570. https://doi.org/10.1016/0016-7037(93)90417-U

Saastamoinen, J., 1981. On the sandstone boulders in the Raahe area. Outokumpu Oy, Unpublished Report 015/2441/ JYS/1981, 13 p. (in Finnish)

Saintilan, N.J.D., Schneider, J.C., Stephens, M., Chiaradia, M., Kouzmanov, K., Wälle, M. \& Fontboté, L., 2015a. A middle Ordovician age for the Laisvall sandstone-hosted $\mathrm{Pb}-\mathrm{Zn}$ deposit, Sweden: A response to early Caledonian orogenic activity. Economic Geology 110, 1779-1801. https://doi.org/10.2113/econgeo.110.7.1779

Saintilan, N.J., Stephens, M.B., Lundstam, E. \& Fontboté, L., 2015b. Control of reactivated basement structures on sandstone-hosted $\mathrm{Pb}-\mathrm{Zn}$ deposits along the Caledonian Front, Sweden: evidence from airborne magnetic field data, structural analysis and ore grade modeling. Economic Geology 110, 91-117. https://doi.org/10.2113/econgeo.110.1.91

Saintilan, N.J., Spangenberg, J.E., Samankassou, E., Kouzmanov, K., Chiaradia, M., Stephens, M.B. \& Fontboté, L., 2016. A refined genetic model for the Laisvall and Vassbo Mississippi Valley-type sandstonehosted deposits, Sweden: constraints from paragenetic studies, organic geochemistry, and $\mathrm{S}, \mathrm{C}, \mathrm{N}$, and $\mathrm{Sr}$ isotope data. Mineralium Deposita 51, 639-664.

DOI 10.1007/s00126-015-0627-7

Saintilan, N.J., Stephens, M.B., Spikings, R., Schneider, J., Chiaradia, M., Spangenberg, J.E., Ulianov, A. \& Fontboté, L., 2017. Polyphase vein mineralization in the Fennoscandian Shield at Åkerlandet, Järvsand, and Laisvall along the erosional front of the Caledonian orogen, Sweden. Mineralium Deposita 52, 823-844. DOI 10.1007/s00126-016-0698-0

Sangster, D., 2018. Discussion: A refined genetic model for the Laisvall and Vassbo Mississippi Valley-type sandstonehosted deposits, Sweden: constraints from paragenetic studies, organic geochemistry, and S, C, N, and Sr isotope data. Mineralium Deposita 53, 293-294. https://doi.org/10.1007/s00126-015-0627-7

Schweda, P. \& Johansson, Å., 1984. Isotopic composition of ore lead in the $\mathrm{Pb}-\mathrm{Zn}$ deposits of the Dorotea district, central Swedish Caledonides. GFF 106, 33-39.

Scott, S.D. 1976. Application of the sphalerite geobarometer to regionally metamorphosed terrains. American Mineralogist 61, 661-670.

Sherlock, S.C., Lucks, T., Kelley, S.P. \& Barnicoat, A., 2005. A high resolution record of multiple diagenetic events: Ultraviolet laser microprobe Ar/Ar analysis of zoned K-feldspar overgrowths. Earth and Planetary Science Letters 238, 329-341. https://doi.org/10.1016/j.epsl.2005.07.018

Simonen, A. 1960. Pre-Quaternary rocks in Finland. Bulletin de la Commission géologique de Finlande 191, 49 p. 
Simonen, A. \& Kouvo, O., 1955. Sandstones in Finland. Bulletin de la Commission géologique de Finlande 168, 57-87.

Stacey, J.S. \& Kramers, J.D., 1975. Approximation of terrestrial lead isotope evolution by a two-stage model. Earth and Planetary Science Letters 26, 207-221.

Tullborg, E.-L., Drake, H. \& Sandström, B., 2008. Palaeohydrogeology: A methodology based on fracture mineral studies. Applied Geochemistry 23, 1881-1897. https://doi.org/10.1016/j.apgeochem.2008.02.009

Tynni, R. \& Uutela, A., 1984. Microfossils from the Precambrian Muhos formation in Western Finland. Geological Survey of Finland, Bulletin 330, 38 p.

Tynni, R. \& Donner, J. 1980. A microfossil and sedimentation study of the Late Precambrian formation of Hailuoto, Finland. Geological Survey of Finland, Bulletin 311, 27 p.

Uutela, A., 1998. Extent of the northern Baltic Sea during the Early Palaeozoic era - new evidence from Ostrobothnia, western Finland. Bulletin of the Geological Society of Finland 70, 51-68.

https://doi.org/10.17741/bgsf/70.1-2.004

Vaasjoki, M., 1977. Rapakivi granites and other postorogenic rocks in Finland: their age and the lead isotopic composition of certain associated galena mineralizations. Geological Survey of Finland, Bulletin 294, 64 p.

Vaasjoki, M., 1981. The lead isotopic composition of some Finnish galenas. Geological Survey of Finland, Bulletin $316,32 \mathrm{p}$.

Vaasjoki, M., 1989. Pb and S isotopic studies on the Rauhala $\mathrm{Zn}-\mathrm{Cu}-\mathrm{Pb}$ sulphide deposit and its environment. Geological Survey of Finland, Special Paper 11, 59-65.

Vaasjoki, M. \& Vivallo, W., 1990. New lead isotope determination from five Proterozoic sulfide deposits, Skellefte district, Sweden. Mineralium Deposita 25, 5056. https://doi.org/10.1007/BF03326383
Vaasjoki, M., Korsman, K. \& Koistinen, T., 2005. Overview. In: Lehtinen, M., Nurmi, P.A., Rämö, O.T. (Eds.), Precambrian Geology of Finland - Key to the Evolution of the Fennoscandian Shield. Elsevier B.V., Amsterdam, p. $1-18$.

Veltheim, V., 1969. On the pre-Quaternary geology of the Bothnian Bay area in the Baltic Sea. Bulletin de la Commission géologique de Finlande 239, 56 p.

Wanke, A. \& Melezhik, V., 2005. Sedimentary and volcanic facies recording the Neoarchaean continent breakup and decline of the positive $\delta^{13} \mathrm{C}_{\text {carb }}$ excursion. Precambrian Research 140, 1-35. https://doi.org/10.1016/j.precamres.2005.05.003

Wannäs, K., 1989. Seismic stratigraphy and tectonic development of the Upper Proterozoic to Lower Paleozoic of the Bothnian Bay, Baltic Sea. Stockholm Contribution in Geology 40(3), 83-168.

Willdén, M., 2004. The Laisvall sandstone-hosted Pb-Zn deposit: Geological overview. In: Allen, R. L., Martinsson, O., Weihed, P. (eds.), Economic Geology, Guidebook Series 33, 115-127. https://doi.org/10.5382/GB.33

Winterhalter, B., 2000. Sedimentary rocks underlying the Gulf of Bothnia. Geological Survey of Finland, Special Paper $28,76-77,79$.

Winterhalter, B., Flodén, T., Ignatius, H., Axberg, S. \& Niemistö, L., 1981. Geology of the Baltic Sea. In: Voipio, A. (ed.), The Baltic Sea. Elsevier, Amsterdam, pp. 1-121.

Wood, D.A., 1980. The application of a Th-Hf-Ta diagram to problems of tectonomagmatic classification and to establishing the nature of crustal contamination of basaltic lavas of the British Tertiary volcanic province. Earth and Planetary Science Letters 50, 11-30. https://doi.org/10.1016/0012-821X(80)90116-8 